\title{
Pore Fluid Evolution Influenced by Volcanic Activities and Related Diagenetic Processes in a Rift Basin: Evidence from the Paleogene Medium-Deep Reservoirs of Huanghekou Sag, Bohai Bay Basin, China
}

\author{
Zhongheng Sun, ${ }^{1,2}$ Hongtao Zhu, ${ }^{1,2}$ Changgui Xu, ${ }^{3}$ Xianghua Yang, ${ }^{1,2}$ \\ Xiaofeng Du, ${ }^{3}$ Qingbin Wang, ${ }^{3}$ and Jinyang Qiao ${ }^{1,2}$ \\ ${ }^{1}$ Key Laboratory of Tectonics and Petroleum Resources, China University of Geosciences, Ministry of Education, Wuhan 430074, China \\ ${ }^{2}$ Faculty of Earth Resources, China University of Geosciences, Wuhan 430074, China \\ ${ }^{3}$ Tianjin Branch of China National Offshore Oil Company Ltd., Tianjin 300452, China
}

Correspondence should be addressed to Hongtao Zhu; htzhu@cug.edu.cn

Received 3 March 2017; Revised 20 May 2017; Accepted 6 June 2017; Published 13 July 2017

Academic Editor: Shuichang Zhang

Copyright (C) 2017 Zhongheng Sun et al. This is an open access article distributed under the Creative Commons Attribution License, which permits unrestricted use, distribution, and reproduction in any medium, provided the original work is properly cited.

\begin{abstract}
Volcanic activities exert a significant influence on pore fluid property and related diagenetic processes that substantially controlled reservoirs quality. Analysis of Paleogene medium-deep sandstones on the Huanghekou Sag provides insight into relating the diagenetic processes to pore fluid property evolution influenced by volcanic activities. Three distinct types of pore fluids were identified on the basis of an integrated and systematic analysis including core and thin section observation, XRD, SEM, CL, and trace element. Alkaline aqueous medium environment occurred in $\mathrm{E}_{2} \mathrm{~s}_{1+2}$ where volcanic activities have insignificant influence on pore fluids, evidenced by typical alkaline diagenetic events such as K-feldspar albitization, quartz dissolution, feldspar dissolution, and carbonate cementation. During the deposition of $\mathrm{E}_{3} \mathrm{~d}_{3}$, influx of terrestrial freshwater and alteration of ferromagnesianrich pore water result in the formation of mixing aqueous medium environment through volcanic eruption dormancy causing zeolite dissolution, clay mineral transformation, and K-feldspar albitization. Ferromagnesian-rich aqueous medium environment developed resulting from the intensive hydrolysis of the unstable ferromagnesian minerals formed due to intense volcanic activities during $\mathrm{E}_{3} \mathrm{~d}_{1+2}$ and corresponding predominant diagenetic processes were characterized by the precipitation and dissolution of lowsilica zeolites. Therefore, the differential properties of pore fluids caused various diagenetic processes controlling reservoir quality.
\end{abstract}

\section{Introduction}

It has been documented that thousands of drilled wells show the tremendously exploratory potential of deep sedimentary formations, which has recently drawn great attention of petroleum geologists worldwide (e.g., [1-3]). The definition of the medium-deep or deep reservoirs differs from basin to basin conventionally depending on basin type and exploration degree. Bohai Bay Basin, one of the most petroliferous basins in China [4], and the medium-deep reservoirs are significant exploration interests commonly defined as those Paleogene intervals at burial depth more than $2500 \mathrm{~m}$ (e.g., [5-7]) but in the study area of Huanghekou Sag it is generally referred to those not deeper than $3500 \mathrm{~m}$ due to special geological settings. A clear understanding of Paleogene reservoirs development is therefore of great significance for optimizing petroleum exploration and increasing reserves.

Pore fluid evolution exerts a critical role in fluid-rock interactions (e.g., [9-12]). Sources of pore fluids are variable which mainly derived from connate water [13], meteoric water [14-16], dehydration of minerals (e.g., gypsum or clay mineral [17-19]), deep compaction brines [20], and hydrothermal water introduced by igneous activities [18]. In most cases, however, the pore fluids are initially only one of them or mixture of them geochemically with different signatures. Thus, the pore fluids are easily altered by dissolution 


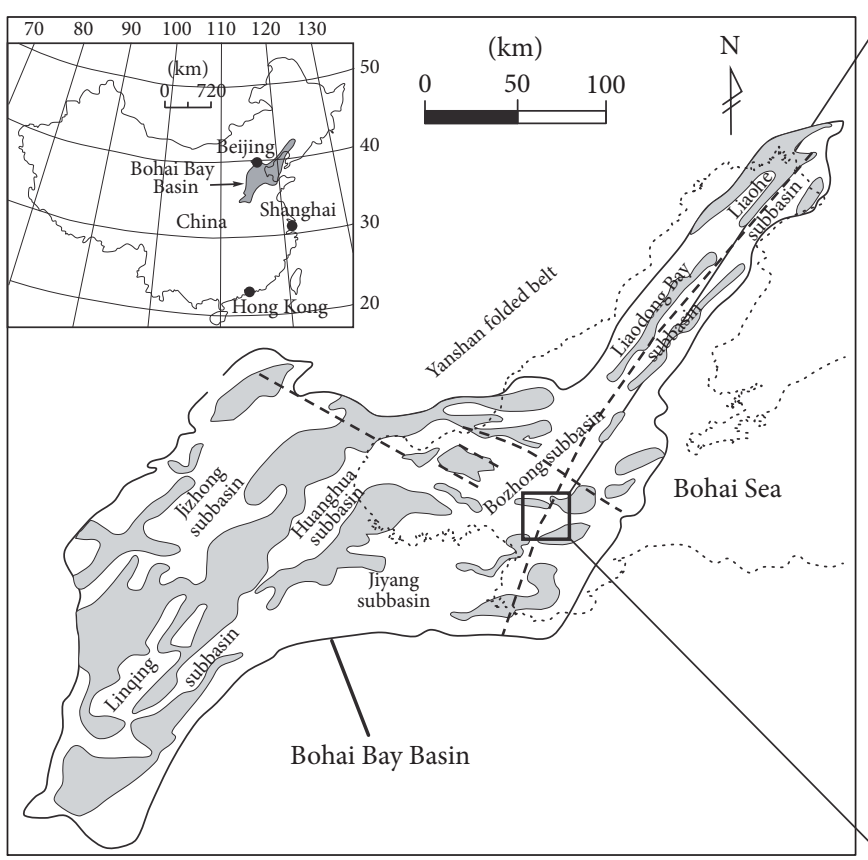

$\longrightarrow$ Basin boundary
\[ \ddots \cdots \cdot \text { Coastline } \]

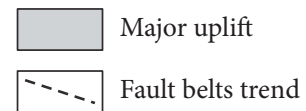

(a)
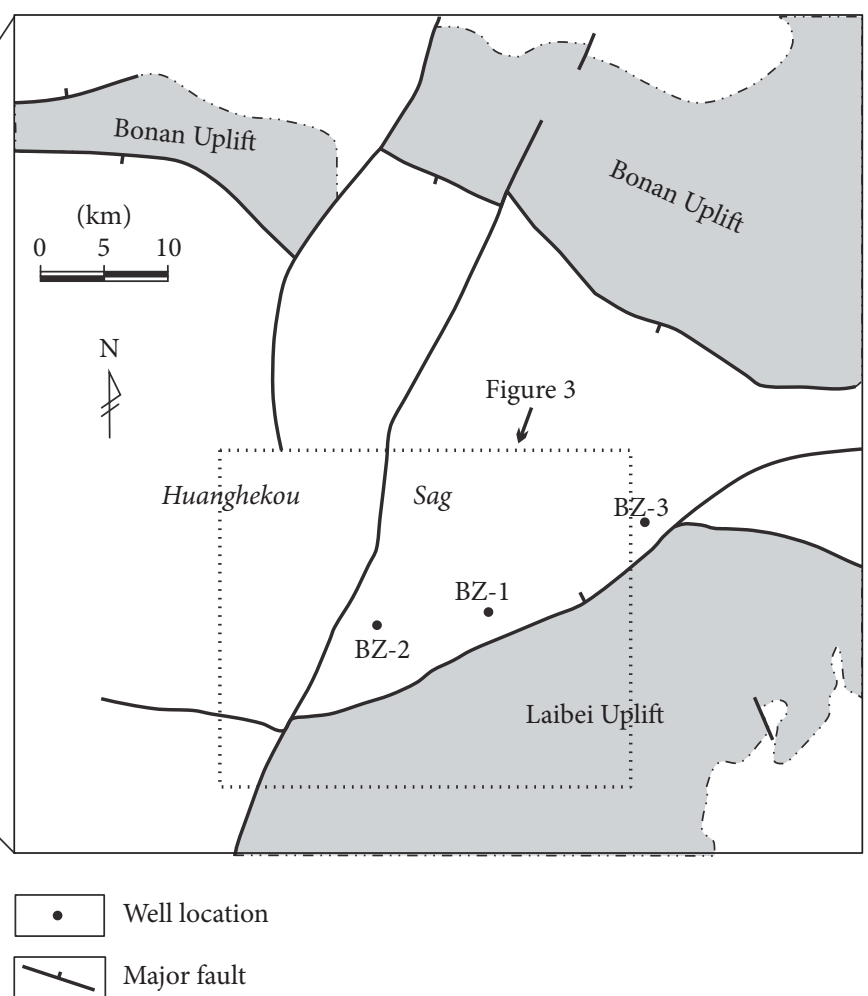

(b)

Figure 1: (a) Location map of subbasins of the Bohai Bay Basin, eastern China (modified from [8]). (b) Map of the Huanghekou Sag showing the distribution of major faults and wells.

and precipitation of minerals, expulsion of organic $\mathrm{CO}_{2}$ and acids, volcanic eruption (e.g., [15, 16, 21, 22]), or mixing with other fluids (e.g., abundance of ferromagnesian caused by basalt eruption) during progressive burial. Different fluid sources and interactions in the reservoir pore have a vital impact on pore fluid property evolution, and thus, to a large extent, will influence the diagenesis and reservoir quality (denotes reservoir porosity and permeability in this paper). Therefore, pore fluid evolution and related diagenetic processes are complicated and variable $[2,23]$, which can induce strong reservoir heterogeneity $[24,25]$. In an attempt to shed light on pore fluid evolution during progressive burial it is thus essential for predicting diagenetic processes and development of hydrocarbon reservoirs (e.g., [10, 26]).

A large number of case studies associated with pore fluid evolution and diagenesis have been made over the past decades, with most works focused on the small scale sandstone reservoirs with nonvolcanic development [9-12, 21, 22]. So far, however, there are few reports that have focused on the reservoir quality in the study area sandstone influenced by volcanic activities but had not investigated the pore fluid evolution associated with volcanic activities and their impacts on diagenetic process [27]. The study area of Huanghekou Sag had undergone multiphase of volcanic eruption during the Paleogene where the aqueous medium is strongly altered by hydrolization of chemically unstable ferromagnesian minerals. Various types of pore fluids developed in Paleogene medium-deep reservoirs $\left(E_{2} s_{1+2}, E_{3} d_{3}, E_{3} d_{1+2}\right)$, which controlled the reservoir quality that is better than that of adjacent areas with no volcanic eruption, providing an excellent example to investigate the properties of pore fluid aqueous medium evolution influenced by volcanic activities. The objectives of this study are to (1) understand pore fluid evolution influenced by volcanic activities, (2) relate the diagenetic processes to pore fluid property evolution, and (3) evaluate controls of different diagenesis on reservoir quality. These objectives will be achieved by an integrated analysis of petrology, mineralogy and trace element compositions combined with a range of analytical techniques. The study provides a useful analogue for understanding the pore fluid evolution of the mediumdeep reservoirs that share similar geological settings.

\section{Geological Setting}

The Bohai Bay Basin, one of the most petroliferous basins in China [4], is located on the eastern coast of China (Figure 1), covering an area of approximately $200,000 \mathrm{~km}^{2}$ $\left(77,220 \mathrm{mi}^{2}\right)$. The Bohai Bay Basin is a complex Cenozoic lacustrine rift basin that formed in the Late Jurassic through the early Tertiary on the north China craton. Generally, the tectonic evolution of the basin is subdivided into two major stages ([28-30]; Figure 2), namely, a synrift stage between 65 and $24.6 \mathrm{Ma}$ and a postrift stage from $24.6 \mathrm{Ma}$ to the present, respectively. The Bohai Bay Basin contains several 

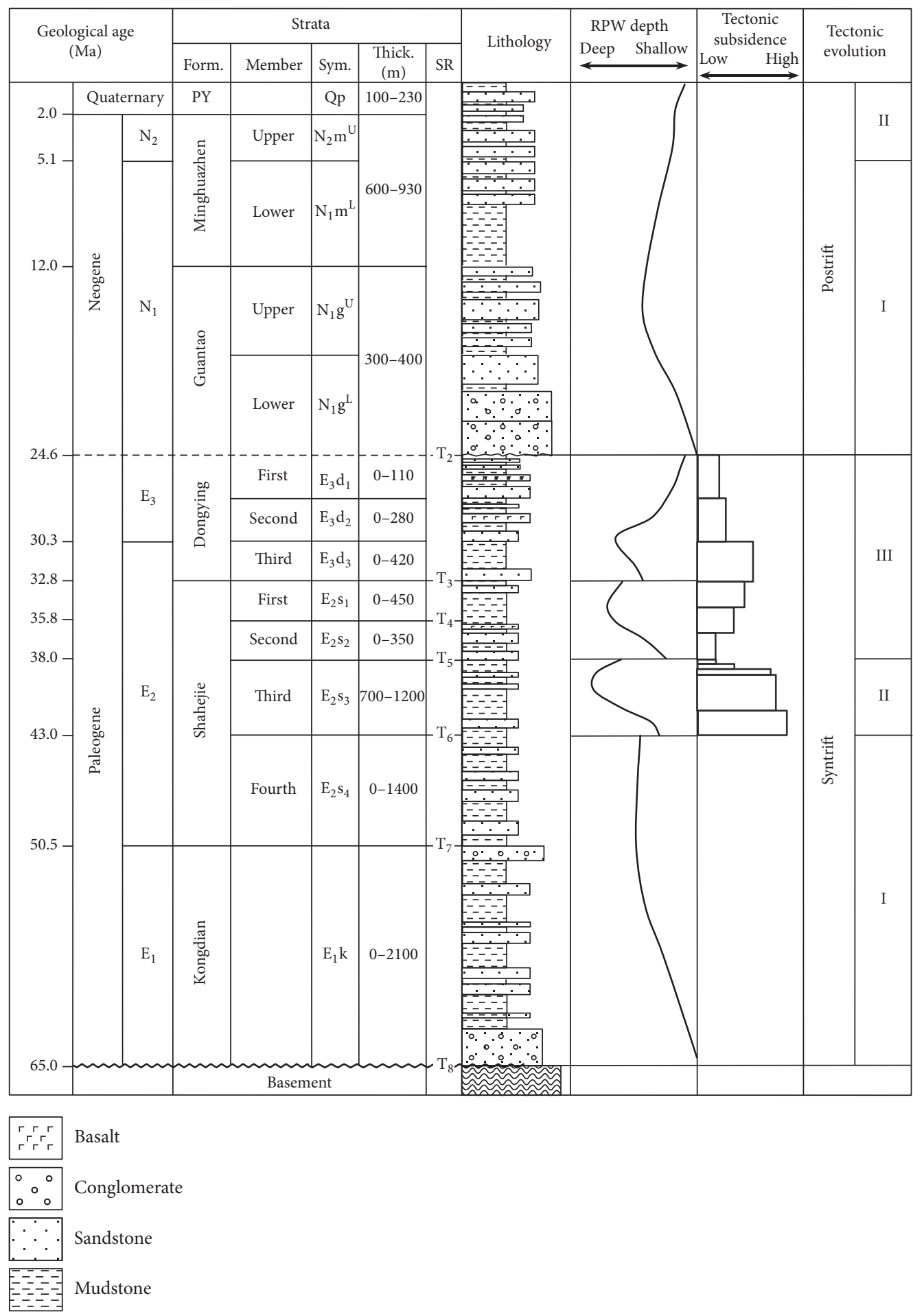

Form. = formation; PY = pingyuan; $\mathrm{SR}=$ seismic reference; RPW depth = relative paleowater depth; Sym. = symbol.

FIGURE 2: Generalized stratigraphic column of the Bohai Bay Basin (modified from [8]). Labels I, II, and III in the far right column mark the tectonic substages of the synrift and postrift.

subbasins (Figure 1(a)). The Huanghekou Sag is located in the southern part of the Bozhong Subbasin of the Bohai Bay Basin and has an area of approximately $3,600 \mathrm{~km}^{2}$ $\left(1,390 \mathrm{mi}^{2}\right)$, bordered in the north by the Bonan Uplift and in the south by the Laibei Uplift (Figures 1(a) and $1(b))$.

Sediments filled in the Huanghekou Sag, in ascending order, are composed of the the Paleogene Kongdian 
TABLE 1: Percentages of detrital grains and structural characteristic from the Paleogene sandstones of well BZ-1, Huanghekou Sag.

\begin{tabular}{|c|c|c|c|c|c|c|c|c|c|c|}
\hline \multirow{2}{*}{ Strata } & \multirow{2}{*}{ Depth (m [ft]) } & \multicolumn{3}{|c|}{ Structure } & \multicolumn{6}{|c|}{ Detrital grains (\%) } \\
\hline & & Gs & Psephicity & Sorting & $\mathrm{Q}$ & $\mathrm{Pl}$ & $\mathrm{Kf}$ & $\mathrm{Vd}$ & $\mathrm{Md}$ & M \\
\hline $\mathrm{E}_{3} \mathrm{~d}_{1}$ & $2255(7398)$ & Mcg & $\mathrm{Sa}-\mathrm{Sr}$ & Moderate & 25 & 15 & 22 & 28 & 10 & 0 \\
\hline $\mathrm{E}_{3} \mathrm{~d}_{1}$ & $2258(7408)$ & Fmg & $\mathrm{Sa}-\mathrm{Sr}$ & Moderate & 33 & 5 & 43 & 6 & 12 & 1 \\
\hline $\mathrm{E}_{3} \mathrm{~d}_{1}$ & $2265(7431)$ & $\mathrm{Mg}$ & $\mathrm{Sa}-\mathrm{Sr}$ & Good & 32 & 4 & 44 & 5 & 14 & 1 \\
\hline $\mathrm{E}_{3} \mathrm{~d}_{1}$ & $2280(7480)$ & $\mathrm{Mg}$ & $\mathrm{Sa}-\mathrm{Sr}$ & Good & 18 & 0 & 33 & 30 & 16 & 3 \\
\hline $\mathrm{E}_{3} \mathrm{~d}_{1}$ & $2354(7723)$ & $\mathrm{Fg}$ & $\mathrm{Sa}-\mathrm{Sr}$ & Good & 34 & 5 & 40 & 6 & 14 & 1 \\
\hline $\mathrm{E}_{3} \mathrm{~d}_{1}$ & $2356(7730)$ & $\mathrm{Hg}$ & $\mathrm{Sa}-\mathrm{Sr}$ & Poor & 35 & 5 & 31 & 9 & 20 & 0 \\
\hline $\mathrm{E}_{3} \mathrm{~d}_{3}$ & $2826(9271)$ & Mfg & $\mathrm{Sa}-\mathrm{Sr}$ & Poor & 33 & 10 & 30 & 18 & 9 & 0 \\
\hline $\mathrm{E}_{3} \mathrm{~d}_{3}$ & $2903(9524)$ & $\mathrm{Fg}$ & $\mathrm{Sr}$ & Good & 30 & 12 & 27 & 22 & 8 & 1 \\
\hline $\mathrm{E}_{3} \mathrm{~d}_{3}$ & 2925 (9596) & $\mathrm{Mg}$ & $\mathrm{Sa}-\mathrm{Sr}$ & Good & 28 & 8 & 24 & 28 & 11 & 1 \\
\hline $\mathrm{E}_{3} \mathrm{~d}_{3}$ & 2944 (9659) & $\mathrm{Fg}$ & $\mathrm{Sa}-\mathrm{Sr}$ & Good & 35 & 7 & 28 & 17 & 9 & 4 \\
\hline $\mathrm{E}_{3} \mathrm{~d}_{3}$ & 2953 (9688) & $\mathrm{Mg}$ & $\mathrm{Sa}-\mathrm{Sr}$ & Moderate & 30 & 5 & 40 & 17 & 8 & 0 \\
\hline $\mathrm{E}_{3} \mathrm{~d}_{3}$ & 2957 (9701) & $\mathrm{Mg}$ & $\mathrm{Sa}-\mathrm{Sr}$ & Moderate & 30 & 6 & 36 & 19 & 9 & 0 \\
\hline $\mathrm{E}_{2} \mathrm{~s}_{1}$ & 3045 (9990) & Fg & $\mathrm{Sa}-\mathrm{Sr}$ & Good & 33 & 5 & 36 & 16 & 8 & 2 \\
\hline $\mathrm{E}_{2} \mathrm{~s}_{1}$ & $3060(10,039)$ & Fmg & $\mathrm{Sa}-\mathrm{Sr}$ & Moderate & 32 & 10 & 27 & 19 & 12 & 0 \\
\hline $\mathrm{E}_{2} \mathrm{~s}_{2}$ & $3081(10,108)$ & Fmg & $\mathrm{Sa}-\mathrm{Sr}$ & Moderate & 31 & 5 & 34 & 22 & 8 & 0 \\
\hline $\mathrm{E}_{2} \mathrm{~s}_{2}$ & $3084(10,118)$ & Cmg & $\mathrm{Sa}-\mathrm{Sr}$ & Moderate & 32 & 6 & 32 & 18 & 12 & 0 \\
\hline $\mathrm{E}_{2} \mathrm{~s}_{2}$ & $3090(10,138)$ & Fmg & $\mathrm{Sa}-\mathrm{Sr}$ & Moderate & 30 & 5 & 36 & 20 & 8 & 1 \\
\hline
\end{tabular}

BZ-1 = Bozhong-1; Cmg = coarse-medium grained; $\mathrm{E}_{3} \mathrm{~d}_{1}=$ first member of the Paleogene Dongying Formation; $\mathrm{E}_{3} \mathrm{~d}_{3}=$ third member of the Paleogene Dongying Formation; $E_{2} s_{1}=$ first member of the Paleogene Shahejie Formation; $E_{2} s_{2}=$ second member of the Paleogene Shahejie Formation; Fg = fine grained; Fmg = fine-medium grained; $\mathrm{Gs}=$ grain size; $\mathrm{Hg}$ = heterogranular; $\mathrm{Kf}=\mathrm{K}$-feldspar; $\mathrm{M}=$ mica; $\mathrm{Mcg}=$ medium-coarse grained; $\mathrm{Md}=$ metamorphic detritus; $\mathrm{Mfg}$ = medium-fine grained; $\mathrm{Mg}=$ medium grained; $\mathrm{Pl}=$ plagioclase; $\mathrm{P}$ = psephicity; $\mathrm{Q}$ = quartz; $\mathrm{Sa}-\mathrm{Sr}$ = subangular-subrounded; $\mathrm{Sr}=$ subrounded; $\mathrm{Vd}$ = volcanic detritus.

(Ek), Shahejie (Es) and Dongying (Ed) formations, Neogene Guantao (Ng) and Minghuazhen (Nm) formations, and the Quaternary Pingyuan (Qp) Formation (Figure 2). The Paleogene Shahejie (Es) interval in the Huanghekou Sag is subdivided into four units $\left(E_{2} s_{4}, E_{2} s_{3}, E_{2} s_{2}\right.$, and $E_{2} s_{1}$ [the first member of the Paleogene Shahejie Formation]), whereas the Dongying (Ed) Formations are composed of three units $\left(E_{3} d_{3}, E_{3} d_{2}\right.$, and $E_{3} d_{1}$ [the first member of the Paleogene Dongying Formation]). Note that $\mathrm{E}_{2} \mathrm{~s}_{2}$ and $\mathrm{E}_{2} \mathrm{~s}_{1}$ intervals are referred to as $\mathrm{E}_{2} \mathrm{~s}_{1+2}$ for short in this paper and $E_{3} d_{2}$ and $E_{3} d_{1}$ intervals are referred to as $E_{3} d_{1+2}$ because of similar deposition settings. The Paleogene Shahejie (Es) and Dongying (Ed) Formations, apart from the $\mathrm{E}_{2} \mathrm{~s}_{4}$ and $\mathrm{E}_{2} \mathrm{~s}_{3}$ interval, are the subject of this study. During the deposition of $\mathrm{E}_{2} \mathrm{~s}_{1+2}$ intervals, braided river deltas developed overall the study area with volcanics distributed sporadically at the bottom and top of the $\mathrm{E}_{2} \mathrm{~s}_{2}$ interval and drilled thickness approximately $26 \mathrm{~m}$ accounting for 13.16 percent of the total formation thickness of the $\mathrm{E}_{2} \mathrm{~s}_{2}$ interval. However, there is no significant volcanics drilled for $\mathrm{E}_{3} \mathrm{~d}_{3}$ that experienced rapid subsidence and lacustrine mudstones are developed in the central of the Huanghekou Sag interfingered with more proximal sandstones of braided river delta. With the continuous volcanic eruption of the lower unit of the second member of the Paleogene Dongying Formation $\left(\mathrm{E}_{3} \mathrm{~d}_{2}{ }^{1}\right)$, high paleogeomorphology developed around the well BZ1 of the research area, which impeded the supply of clastic materials and development of braided river delta. Volcanic eruption in the $E_{3} d_{1+2}$ intervals is characterized by more active, multiperiod eruption and widespread distribution [8].
According to the drilling results of well BZ-1, volcanics are drilled up to $91.7 \mathrm{~m}$ with percentage of 21.3 of the total formation thickness of the $E_{3} d_{1+2}$ interval. Examination of thin section in volcanics drilled in the study area indicates that lithology of igneous is mainly basalt.

Most samples in the Paleogene $\mathrm{E}_{2} \mathrm{~s}_{1+2}, \mathrm{E}_{3} \mathrm{~d}_{3}$, and $\mathrm{E}_{3} \mathrm{~d}_{1+2}$ intervals are mainly lithic arkoses. Sandstones of $\mathrm{E}_{2} \mathrm{~s}_{1+2}$ intervals are fine to medium-grained and moderately sorted sandstones of subangular to subrounded psephicity. Based on point-count data (Table 1), detrital quartz $(30 \%-33 \%)$ and feldspar $(37 \%-41 \%)$ are the predominant framework grain and detrital feldspar includes K-feldspar and plagioclase. Detrital K-feldspar is more abundant than plagioclase. Rock fragments $(24 \%-31 \%)$ are less significant and include metamorphic and igneous grains, with acidic igneous rock most. Comparing to $\mathrm{E}_{2} \mathrm{~s}_{1+2}$ intervals, samples in $\mathrm{E}_{3} \mathrm{~d}_{3}$ and $\mathrm{E}_{3} \mathrm{~d}_{1+2}$ have similar framework compositions and rock fragments constituents, but the percentages of each component are substantially different. The content of detrital feldspar in $\mathrm{E}_{3} \mathrm{~d}_{3}$ ranges between $32 \%$ and $45 \%$, detrital quartz varies from $25 \%$ to $35 \%$, and rock fragments range from $25 \%$ to $39 \%$. However, for $\mathrm{E}_{3} \mathrm{~d}_{1+2}$, the contents of detrital feldspar, detrital quartz, and rock fragments are $33 \%-48 \%, 18 \%-35 \%$, and $18 \%-46 \%$, respectively.

\section{Samples and Methods}

The study was focused on the Paleogene medium-deep reservoirs $\left(E_{2} s_{1+2}, E_{3} d_{3}\right.$, and $\left.E_{3} d_{1+2}\right)$ of Huanghekou sag where most of the producing oil fields occur and volcanic 


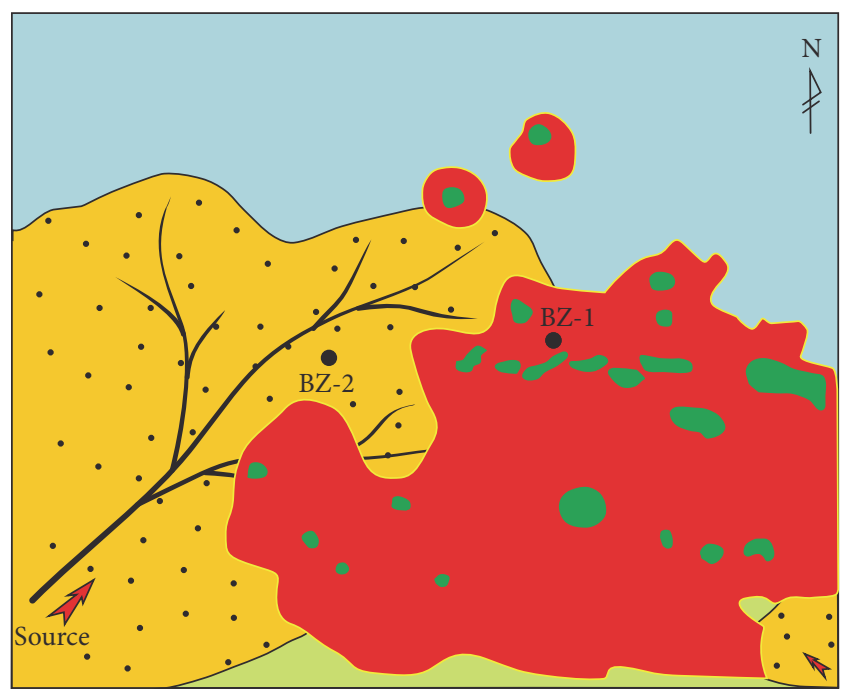

Braid river delta

Shore-shallow lacustrine

Semideep and deep lacustrine

FIGURE 3: Sedimentary facies and volcanics distribution of the first and second members of Dongying Formation $\left(\mathrm{E}_{3} \mathrm{~d}_{1+2}\right)$ based on the interpretation of well and seismic data. The mapping area is shown in Figure 1(b).

activities developed pervasively. Three main oil-producing wells drilled in the study area marked in black dotted line (Figure 1(b)). Previous studies demonstrated the fact that volcanic activities in the first and second members of Dongying Formation $\left(\mathrm{E}_{3} \mathrm{~d}_{1+2}\right)$ are characterized by more active, multiphase eruption and widespread distribution [8]. Well- and seismic-based sedimentary facies and volcanics distribution of $\mathrm{E}_{3} \mathrm{~d}_{1+2}$ indicate that the well BZ-1 located in volcanic overflow facies, surrounded by volcanic conduits displaying beads-shaped distribution (Figure 3). However, both well BZ-2 and well BZ-3 have no significant volcanic overflow facies developed. In other words, well BZ-1 may have experienced stronger influence of volcanic activities than that of the other two wells. Data from well BZ-1 are therefore of optimum choice for investigating the pore fluid evolution influenced by volcanic activities. Core and cuttings samples were collected from well BZ-1 borehole in the Paleogene at depths ranging from 2000 to $3500 \mathrm{~m}$ (6562-11,483 ft).

To quantify different diagenetic products, more than 60 polished thin sections and about 40 blue epoxy resin impregnated thin sections were prepared for rock mineralogy, diagenesis, and visual pore characteristics. Point counting was carried out on thin sections with at least 300 points to examine the correctness of the selected rock composition data. To determine the compositions of authigenic minerals and understand their spatial relationships, an amount of 15 representative samples was prepared using a Quanta 200 environmental scanning electron microscope (ESEM). Ten representative samples were viewed under a FEI Quanta 450 FEG field emission scanning electron microscope (BSE) equipped with backscatter detector (BSE) under an acceleration voltage of $20 \mathrm{kV}$ and sample dip of $70^{\circ}$. In addition, different mineral phases were determined based on highly magnified backscatter electron image methods.

Reconstruction of paleosalinity based on boron in clays is an effective approach documented by using sediments at various time scale [31-34]. Boron-derived paleosalinity reconstructions are based on the direct positively linear relationship between boron in ancient clays and the paleosalinity of the depositional environment $[34,35]$. Hence, to restore the paleosalinity, trace element analysis was carried out using ELE-MENTXR plasma mass spectrum analyzer with ELANDRC-e, measured following the rules of Methods for Chemical Analysis of Silicate Rocks-Part 30: Determination of 44 Elements (National Standard GB/T 14506.302010). Measured temperature and relative moisture for trace element are $20^{\circ} \mathrm{C}$ and $30 \%$, respectively.

Samples were collected for mineralogical analyses using $\mathrm{X}$-ray diffraction (XRD). The XRD patterns of sandstone were obtained using X'pert Pro MPD X-ray diffractometer made in Netherlands with measured temperature of $20^{\circ} \mathrm{C}$ and moisture of $65 \%$ whereas the XRD patterns of mudstone were finished using $\mathrm{D} / \mathrm{max}-2500 \mathrm{X}$-ray diffractometer with measured temperature of $20^{\circ} \mathrm{C}$ and moisture of $50 \%$. Preparation, analysis, and interpretation procedures are modified from Moore and Reynolds [36] and Hillier [37]. Cathode luminescence (CL) analyses for 10 typical samples were performed using an Olympus microscope equipped with a CL8200-MK5 CL instrument.

Among all the analyses above, point counting, XRD of sandstones, SEM, and CL were done in Key Laboratory of China University of Geosciences, whereas XRD of mudstones and trace element analysis were carried out in Institute of Bohai Oilfield.

\section{Results}

A series of diagenetic processes are identified in the Paleogene medium-deep reservoirs, Huanghekou Sag, including precipitation of carbonate, zeolite minerals and dissolution of feldspar, quartz, and zeolite minerals. Precipitation and dissolution of these minerals played a significant role in reservoir quality of the Paleogene medium-deep reservoirs. In addition, these diagenetic products developed in specified aqueous medium environment that can be effectively used to trace pore fluid properties, combined with analysis of trace elements and X-ray diffraction. Minor diagenetic phases (e.g., ferroan dolomite) are not depicted in this study because of leanly abundant through the Paleogene medium-deep intervals.

4.1. Precipitation and Dissolution of Zeolite. Discrete plot of mineral compositions based on XRD analysis of sandstone reservoirs indicates that zeolites occur mainly in the $\mathrm{E}_{3} \mathrm{~d}_{1+2}$ interval with high content, which may be controlled by aqueous medium environment enriched ferromagnesian minerals (Figure 4). Similarly, precipitation and dissolution of zeolites are observed commonly in the $\mathrm{E}_{3} \mathrm{~d}_{1+2}$ interval. In thin sections, zeolites occur as intergranular cements with prismatic perpendicular to basalt rock fragments filling 


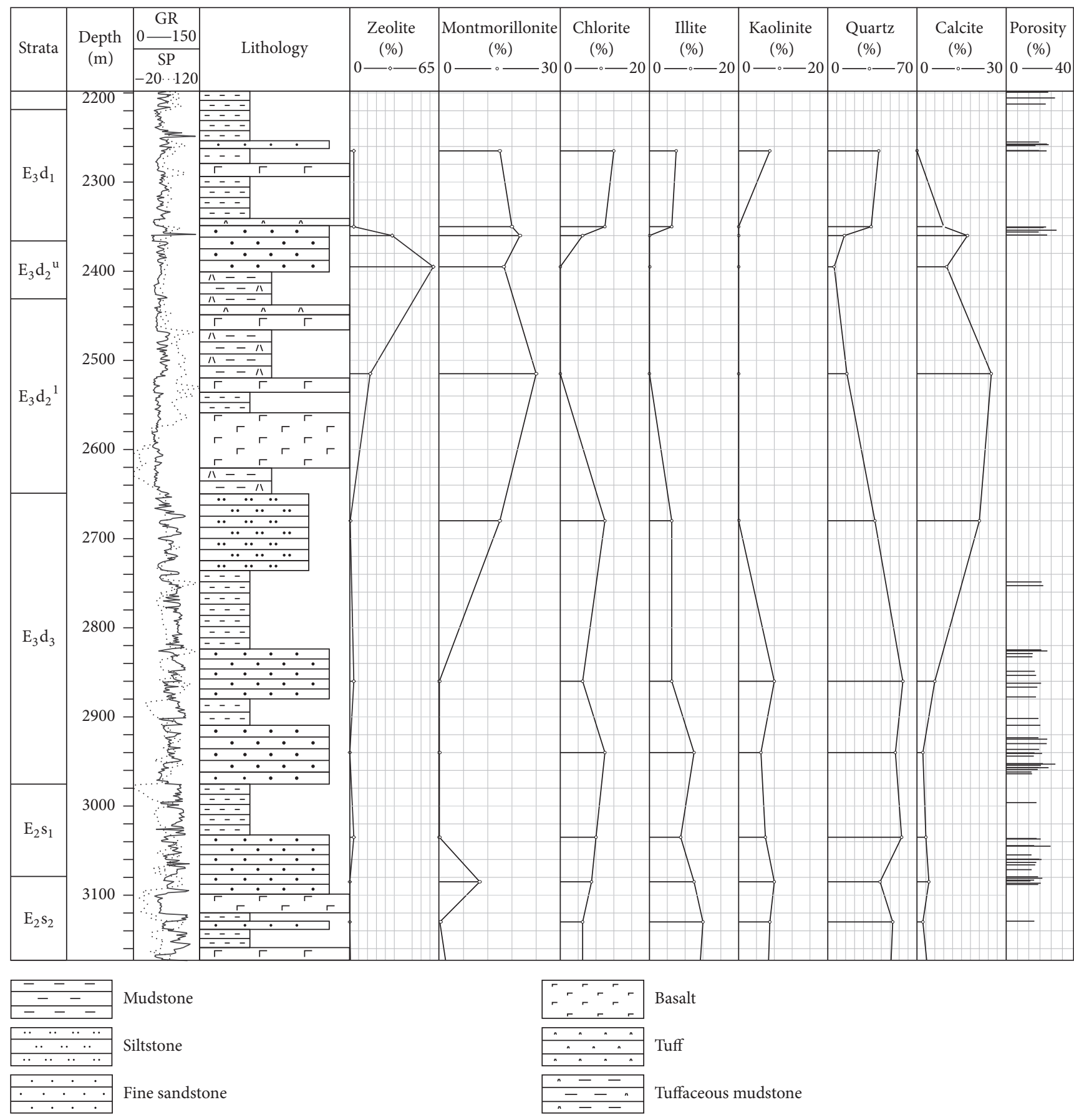

FIGURE 4: Mineralogical composition vertical distribution of reservoir sandstones in BZ-1 well based on X-ray diffraction (XRD) analysis.

intergranular pores (Figure 5(a)). In addition, some interesting phenomena are observed that zeolites replace volcanic fragments, feldspars, and quartz that line intergranular pores. Pore types of the $E_{3} d_{1+2}$ interval occur mainly as zeolite dissolution pore, amygdala dissolution pore based on thin section observation.

4.2. Dissolution of Quartz and Feldspar. Partial to extensive dissolution of detrital quartz grains was observed in the $\mathrm{E}_{2} \mathrm{~s}_{1+2}$ interval (Figures 6(a), 6(b), and 6(c)). Based on microscope observations, two types of quartz dissolution can be identified: (1) quartz grains dissolution occurred along the boundaries and interior of grains, with embayed boundary and vugular shape, respectively; (2) quartz grains dissolution occurred along the internal fracture of grains. Dissolution of detrital feldspar grains is pervasively developed in the Paleogene reservoirs of study area. The predominant dissolved feldspars are K-feldspar grains (Figure 7(a)). Locally, dissolved plagioclase can be observed but is not common. 


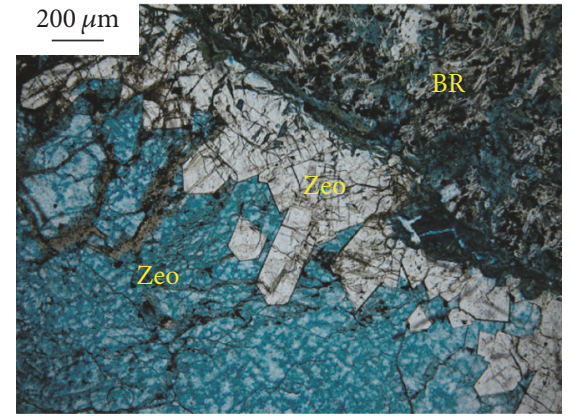

(a)

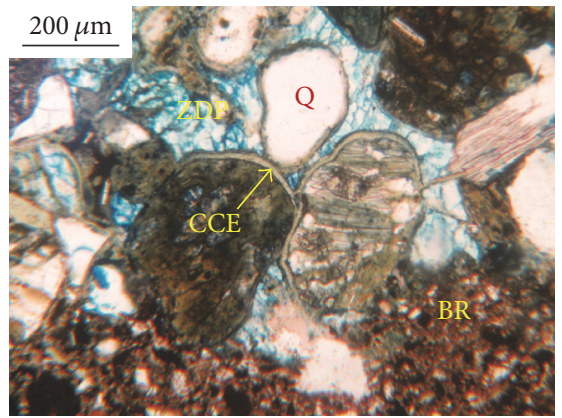

(d)

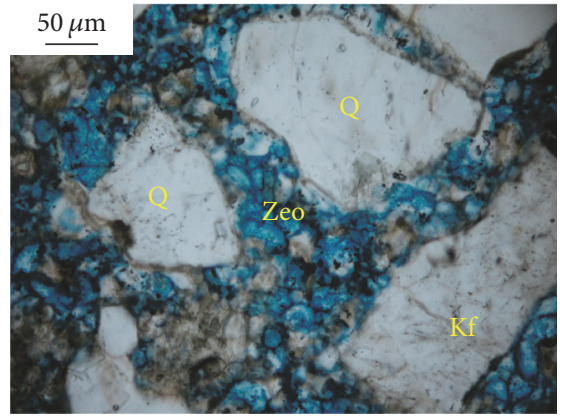

(b)

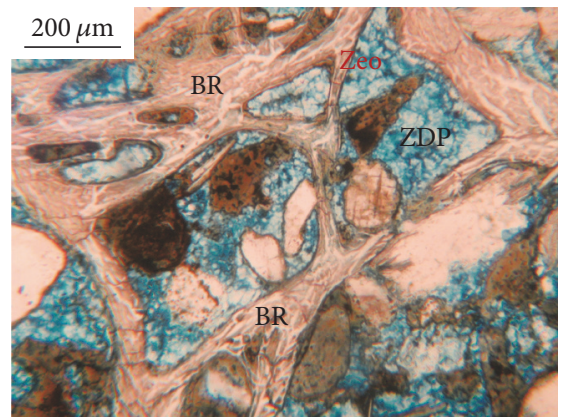

(e)

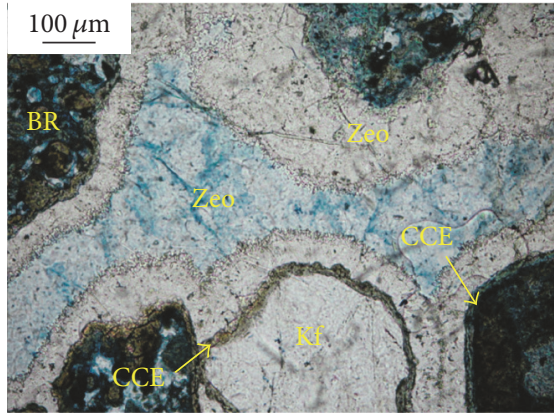

(c)

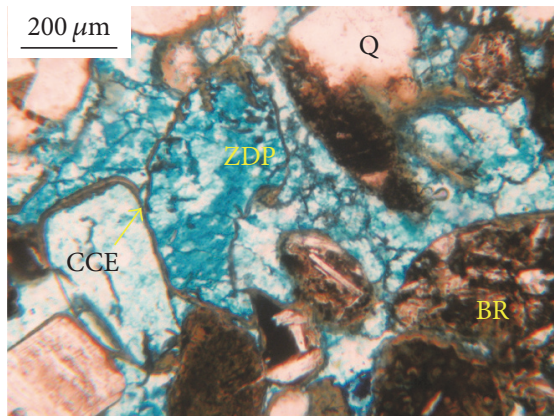

(f)

FIGURE 5: Photomicrographs of zeolite diagenesis and dissolved zeolite related to basalt eruption of the Paleogene sandstone reservoirs in well BZ-1. (a) Zeolite precipitated perpendicular to basalt rock fragments, $\mathrm{E}_{3} \mathrm{~d}_{1}, 2259 \mathrm{~m}$ (7411 ft). (b) Zeolite filled in intergranular pores, $\mathrm{E}_{3} \mathrm{~d}_{1}, 2265 \mathrm{~m}$ (7431 ft). (c) Zeolite developed pervasively and chlorite clay envelope occurred, $\mathrm{E}_{3} \mathrm{~d}, 2351 \mathrm{~m}$ (7713 ft). (d) Micrograph of thin section showing the zeolite partly and completely dissolved and chlorite clay envelope occurred, $\mathrm{E}_{3} \mathrm{~d}_{1}, 2280 \mathrm{~m}$ (7480 ft). (e) Micrograph of thin section showing dissolved amygdaloid pores of zeolite, $\mathrm{E}_{3} \mathrm{~d}_{1}, 2280 \mathrm{~m}(7480 \mathrm{ft})$. (f) Micrograph of thin section showing the zeolite partly and completely dissolved, $\mathrm{E}_{3} \mathrm{~d}_{1}, 2280 \mathrm{~m}(7480 \mathrm{ft}) . \mathrm{BR}=$ basalt rock fragments, $\mathrm{CCE}=$ chlorite clay envelope, $\mathrm{Kf}=\mathrm{K}$-feldspar, $\mathrm{Q}=\mathrm{quartz}, \mathrm{Zeo}$ $=$ zeolite, and $\mathrm{ZDP}=$ zeolite dissolved pore.

4.3. K-Feldspar Albitization. On the basis of environmental scanning electron microscope (ESEM) and backscattered electron (BSE) image analysis, albitization occurred mainly in the $\mathrm{E}_{2} \mathrm{~s}_{1+2}$ interval. Albitization of $\mathrm{K}$-feldspar is predominant the interest area, whereas albitization of plagioclase only can be observed locally (Figures 6(d), 6(e), and 6(f)). In addition, euhedral albite crystals are developed as porefilling cements and as replacement of dissolved K-feldspar and plagioclase (Figure 6(e)). Albitization of K-feldspar is displayed commonly along cleavage planes of detrital feldspar grains (Figure 6(f)).

4.4. Carbonate Cements. Carbonate cements are the volumetrically predominant authigenic minerals in the $\mathrm{E}_{2} \mathrm{~s}_{1+2}$ interval and mainly include calcite, dolomite, and ferroan dolomite. The CL micrograph of calcite cements displays a homogeneous orange luminescence color (Figure 7(c)). In thin sections, dolomite cements cause mainly ctenoid dolomite encrustation around the surface of detrital grains or partly epidermis oolite formed by engulfing quartz grains (Figures $7(\mathrm{~d})$ and $7(\mathrm{f})$ ). Ferroan dolomite is the most pore-filling cements remaining in intergranular pores which resulted in the pore connectivity becoming worse. Ctenoid dolomite encrustation adheres to the surface of detrital grains but inhabited the overgrowth of quartz grains which effectively preserved intergranular pore.

4.5. X-Ray Diffraction of Clay Mineral. Various types of clay minerals with different abundances occur in the Paleogene interbedded mudstones of sandstone reservoirs, as revealed by XRD, composed of illite, mixed-layer illite/smectite (I/S), kaolinite, chlorite, and mixed-layer chlorite/smectite (C/S). $\mathrm{XRD}$ analysis data of interbedded mudstones indicates that illite and mixed-layer illite/smectite are the dominating clay minerals in the whole Paleogene intervals except the $E_{3} d_{1+2}$ interval which may be associated with the eruption of basalt and the content of illite shows positive correlation with increasing burial depth, particularly, deeper than about $2700 \mathrm{~m}$ where it increases sharply (Figure 8). Mixed-layer chlorite/smectite mainly exists at depths shallower than $2800 \mathrm{~m}$ corresponding to the $\mathrm{E}_{3} \mathrm{~d}_{1+2}$ interval and the upper part of $E_{3} d_{3}$ interval and shows decreasing trends with increased burial depth (Figure 8). The content of kaolinite is characterized by significant increase in the lower part of $\mathrm{E}_{3} \mathrm{~d}_{3}$ interval between $2900 \mathrm{~m}$ and $3000 \mathrm{~m}$ with percentage ranging from 10 to $30 \mathrm{~m}$. On the contrary, the percentage of mixed-layer illite/smectite decreases quickly deeper than $2800 \mathrm{~m}$ to $3000 \mathrm{~m}$. Therefore, the contents of the twoclay minerals variation with depth show that obviously 


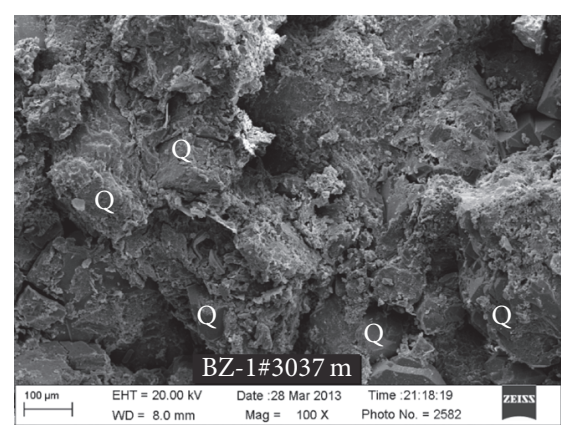

(a)

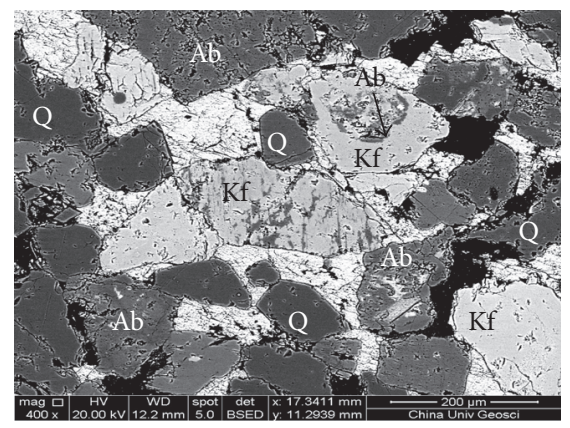

(d)

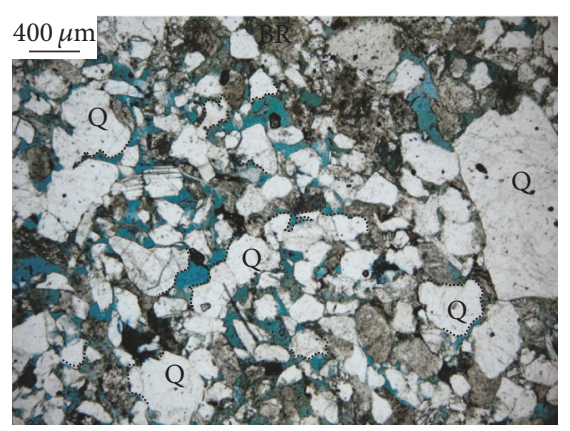

(b)

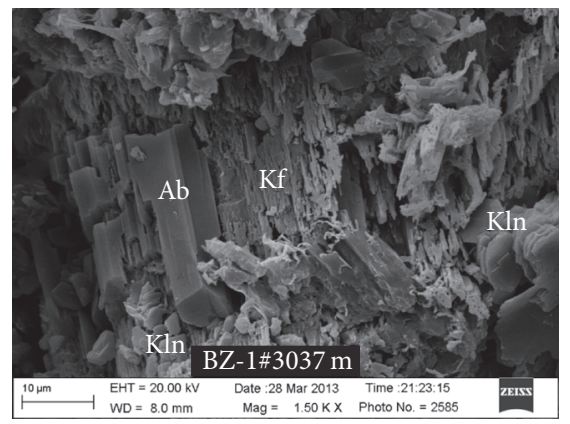

(e)

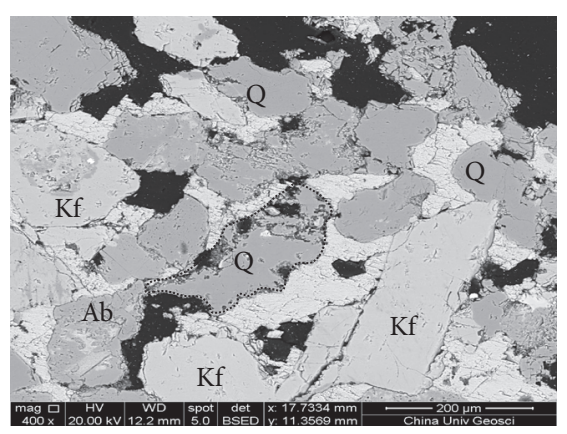

(c)

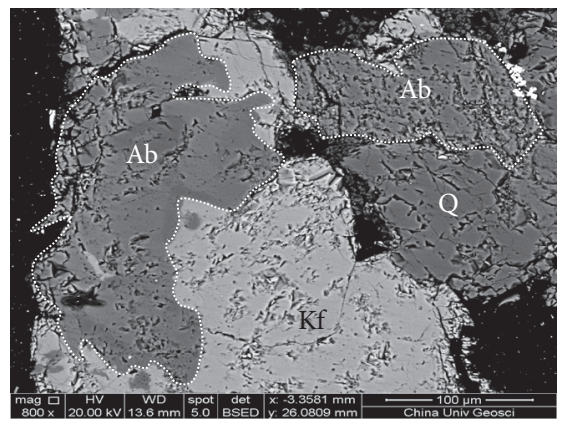

(f)

Figure 6: Photomicrographs of quartz grains dissolution and K-feldspar albitization in the Paleogene sandstone reservoirs in the well BZ1 of Huanghekou Sag. (a) Environmental scanning electron microscope (ESEM) image of dissolved quartz (Q), $\mathrm{E}_{2} \mathrm{~s}_{1}, 3037 \mathrm{~m}(9964 \mathrm{ft}) .(\mathrm{b})$ Dissolution of quartz showing embayed shape (marked with black dot line), $\mathrm{E}_{2} \mathrm{~s}_{1}, 3037 \mathrm{~m}$ (9964 ft). (c) Backscattered electron (BSE) image of quartz dissolution along grain boundary and fracture, $\mathrm{E}_{3} \mathrm{~d}_{3}, 2944 \mathrm{~m}(9659 \mathrm{ft})$. (d) Albitization $(\mathrm{Ab})$ of K-feldspar along cleavage plane, $\mathrm{E}_{3} \mathrm{~d}_{3}$, $2944 \mathrm{~m}, \mathrm{BSE}$ image $\left(9659 \mathrm{ft}\right.$ ). (e) SEM photograph of albite crystals in partly dissolved K-feldspar grain, $\mathrm{E}_{2} \mathrm{~s}_{1}, 3037 \mathrm{~m}$ (9964 ft). (f) K-feldspar was replaced by albite, $\mathrm{E}_{2} \mathrm{~s}_{1}, 3037 \mathrm{~m}(9964 \mathrm{ft}) . \mathrm{Ab}=$ albitization, $\mathrm{Kf}=\mathrm{K}$-feldspar, $\mathrm{Kln}=$ kaolinite, and $\mathrm{Q}=$ quartz.

mirror trends occurred in the lower part of $\mathrm{E}_{3} \mathrm{~d}_{3}$ interval (Figure 8).

4.6. Trace Element Distribution of Paleogene Mudstone. Trace element distribution of well BZ-1 between $\mathrm{E}_{2} \mathrm{~s}_{1+2}, \mathrm{E}_{3} \mathrm{~d}_{3}$, and $E_{3} d_{1+2}$ is characterized by three types of stepped reduction where boron concentrations decrease significantly. Based on analysis of trace elements, boron concentrations of $\mathrm{E}_{2} \mathrm{~s}_{1+2}$ interval and $\mathrm{E}_{3} \mathrm{~d}_{1+2}$ interval are the most and the least, respectively, and $\mathrm{E}_{3} \mathrm{~d}_{3}$ interval is intermediate. Within the $\mathrm{E}_{2} \mathrm{~s}_{1+2}$ interval, concentration of boron increases slightly with increased burial depth ranging from 32.6 to $46.6 \mu \mathrm{g} / \mathrm{g}$ with an average value of $38.16 \mu \mathrm{g} / \mathrm{g}$ (Figure 9). During the $\mathrm{E}_{3} \mathrm{~d}_{3}$ interval, however, the content of boron reduces to level ranging from 15.4 to $33.9 \mu \mathrm{g} / \mathrm{g}$ with an average of $26.8 \mu \mathrm{g} / \mathrm{g}$ (Figure 9). For $\mathrm{E}_{3} \mathrm{~d}_{1+2}$ interval, boron concentrations decrease to a lower interval ranging from 5.51 to $26.5 \mu \mathrm{g} / \mathrm{g}$ with an average value of $10.7 \mu \mathrm{g} / \mathrm{g}$ (Figure 9). Similar trend is shown in the ratios of $\mathrm{B} / \mathrm{Ga}$ element, as revealed in Figure 9, but different in numeric value.

\section{Discussion}

5.1. Evolution of Pore Fluids. The various diagenetic processes in the Paleogene medium-deep reservoirs in the Huanghekou Sag record the pore varying fluid properties. The typically diagenetic events, clay mineral compositions, and trace elements distribution characteristics discussed above demonstrate large difference in the pore fluid properties with different intervals during the burial process of the sandstone reservoirs accompanied by basalt eruption. Therefore, in an attempt to investigate these differences using XRD data and trace elements are necessary.

Different diagenetic events developed in various deposition environment with diverse pore fluid properties that effectively help us understand the pore fluid evolution [12]. Based on thin section observation, as discussed above, typically diagenetic events developed in Paleogene sandstone reservoirs include precipitation and dissolution of zeolite, dissolution of quartz and feldspar, and K-feldspar albitization.

5.1.1. Ferromagnesian Aqueous Medium Environment. Zeolite is alkaline metal aluminum silicate mineral of framework structure essentially formed through the water-rock interactions of volcanic glass whether exogenous or endogenous origin [38]. Previous studies demonstrated that zeolite may develop with various sedimentary environments but commonly formed during the medium-alkaline water environment with $\mathrm{pH}$ value ranging from 7 to 10 and generally related to alteration of volcanic tuff and volcanic glass [3941]. Furthermore, zeolite concentrated on saline alkaline environment which provides the source of $\mathrm{SiO}_{2}$ and $\mathrm{Al}_{2} \mathrm{O}_{3}$ for 


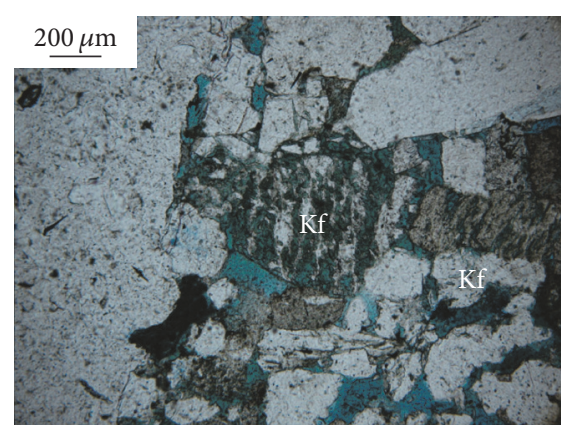

(a)

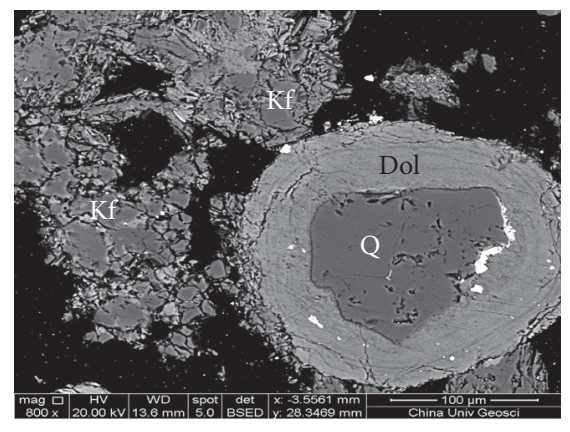

(d)

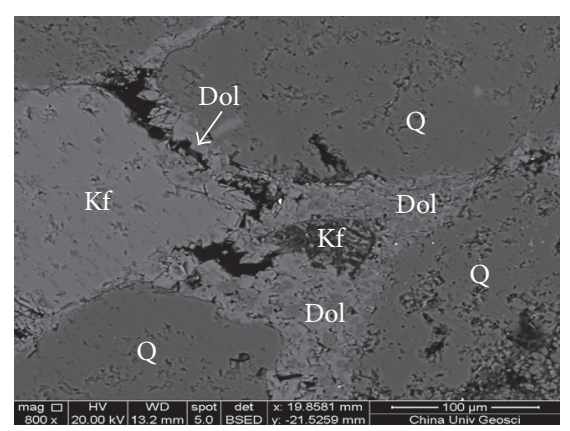

(b)

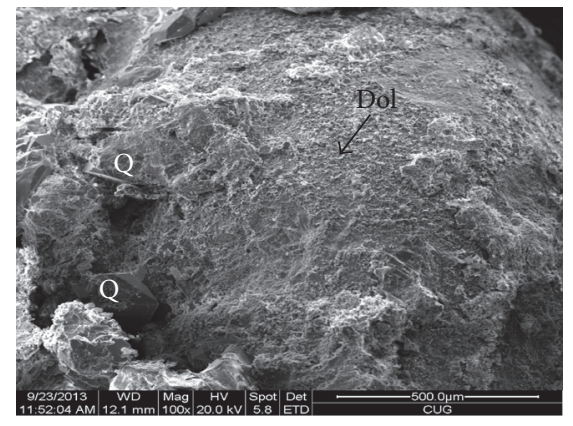

(e)

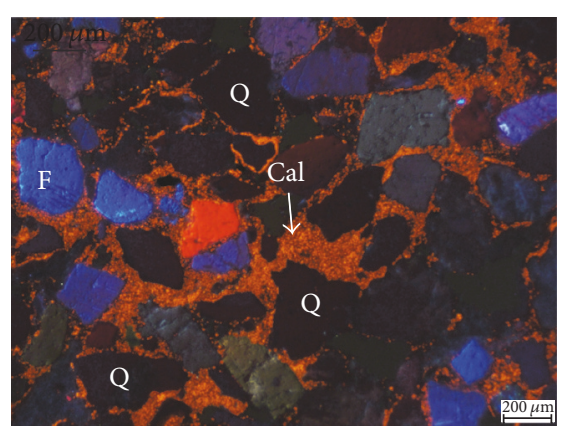

(c)

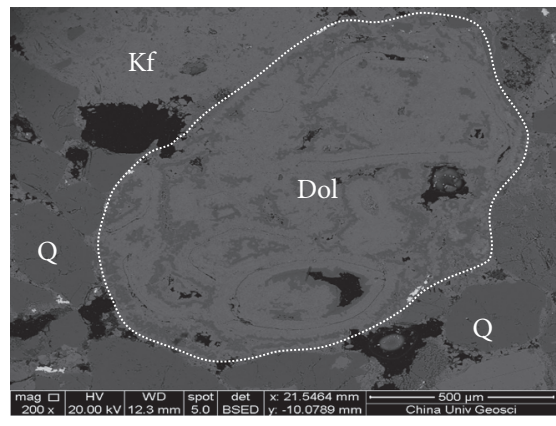

(f)

Figure 7: Photomicrographs of feldspar dissolution and dolomite encrustation in the Paleogene sandstone reservoirs in the well BZ-1 of Huanghekou Sag. (a) K-feldspar (Kf) dissolution, $\mathrm{E}_{2} \mathrm{~s}_{1}, 3037 \mathrm{~m}$ (9964 ft). (b) Backscattered electron (BSE) image of dolomite encrustation, $\mathrm{E}_{2} \mathrm{~s}_{2}, 3084 \mathrm{~m}$ (10,118 ft). (c) Micrograph of CL showing the calcite cements (orange luminescent), $\mathrm{E}_{2} \mathrm{~s}_{2}, 3084 \mathrm{~m}$ (10,118 ft). (d) Micrograph of BSE showing dolomite encrustation around the detrital quartz, $\mathrm{E}_{2} \mathrm{~s}_{1}, 3037 \mathrm{~m}(9964 \mathrm{ft})$. (e) Idem with D but ESEM micrograph, $\mathrm{E}_{2} \mathrm{~s}_{1}, 3037 \mathrm{~m}$ (9964 ft). (f) Micrograph of BSE showing dolomite debris (within the white dotted line) and pectinate dolomite encrustation (outside the white dotted line $), \mathrm{E}_{2} \mathrm{~s}_{2}, 3084 \mathrm{~m}(10,118 \mathrm{ft})$. Cal = calcite, Dol = dolomite, $\mathrm{F}=$ feldspar, $\mathrm{Kf}=\mathrm{K}$-feldspar, Kln = kaolinite, and $\mathrm{Q}=\mathrm{quartz}$.

the precipitation of zeolite. When formation water medium flows through the basalt strata, the released $\mathrm{K}^{+}, \mathrm{Na}^{+}, \mathrm{Ca}^{2+}$, $\mathrm{Al}^{3+}, \mathrm{Fe}^{3+}$, and $\mathrm{Mg}^{2+}$ of basalt resulted in the formation of alkaline water environment with increased $\mathrm{pH}$ and enrichment of ferromagnesian minerals which favors generation of zeolite. Thus, interaction of alkaline aqueous medium and volcanic glass leads to generation of zeolite minerals [40, 4244]. Previous study based on electron microprobe analysis demonstrated that zeolites in well BZ-1 of the study area are mainly analcimes [27]. Analcimes might not be directly formed by the alteration of volcanic glass but transformed by other zeolites (commonly clinoptilolites). Early formed zeolites (clinoptilolite) may react at shallow depths to form analcime, albite, and K-feldspar as a function of either age or salinity. The transformation of clinoptilolite to analcime can be idealized as the following reaction [45], but the actual chemical change is commonly more complex than this.

$$
\begin{aligned}
\mathrm{Na}_{1.02} & \mathrm{~K}_{0.82} \mathrm{Ca}_{0.15} \mathrm{Al}_{2.26} \mathrm{Si}_{9.84} \mathrm{O}_{24} \cdot 8 \mathrm{H}_{2} \mathrm{O} \text { (clinoptilolite) } \\
+ & 1.14 \mathrm{Na}^{+} \\
\longrightarrow & 2.16 \mathrm{NaAlSi}_{2.57} \mathrm{O}_{7.14} \cdot \mathrm{H}_{2} \mathrm{O} \text { (analcime) } \\
& +0.15 \mathrm{Ca}^{2+}+0.82 \mathrm{~K}^{+}+4.29 \mathrm{SiO}_{2}+5.8 \mathrm{H}_{2} \mathrm{O}
\end{aligned}
$$

Given that, it is well explained that high contents of zeolite based on thin section observations and XRD data occurred mainly in the layer $\left(\mathrm{E}_{3} \mathrm{~d}_{1+2}\right)$ containing basalt (Figures 4 and 5). With the influence of basalt eruption, ferromagnesian minerals of basalt in sandstone reservoirs of $E_{3} d_{1+2}$ dissolved led to development of ferromagnesian aqueous medium environments that benefits the formation of zeolite. However, $\mathrm{E}_{3} \mathrm{~d}_{3}$ with no significant influence of basalt eruption is corresponding to less abundance of zeolite. This phenomenon is consistent with clay minerals dominated by mixed layers $\mathrm{C} / \mathrm{S}$ in $\mathrm{E}_{3} \mathrm{~d}_{1+2}$ (Figure 8 ), which can be interpreted as strong hydration and hydrolysis of tuff and eruptive rock detritus precipitated voluminous authigenic smectite at an early diagenesis stage [46-48]. Smectite can easily transform to mixed-layer I/S or discrete illite with increasing temperature where a potassium source exist ([4952]; Cama et al. 2000). Meanwhile, the conversion of smectite to mixed-layer $\mathrm{C} / \mathrm{S}$ occurred where aqueous medium environments were enriched in magnesium. Large amounts of $\mathrm{Fe}^{2+}$ and $\mathrm{Mg}^{2+}$ released due to intense hydrolization of unstable volcanic rock fragments that resulted in pore fluids rich in ferromagnesian provided the condition for the formation of chlorite. Therefore, that is why the content of mixed-layer $\mathrm{C} / \mathrm{S}$ of $\mathrm{E}_{3} \mathrm{~d}_{1+2}$ increases abruptly as shown by $\mathrm{XRD}$ analysis (Figure 8).

5.1.2. Alkaline Aqueous Medium Environment. For a long time, quartz is considered to be chemically stable mineral 


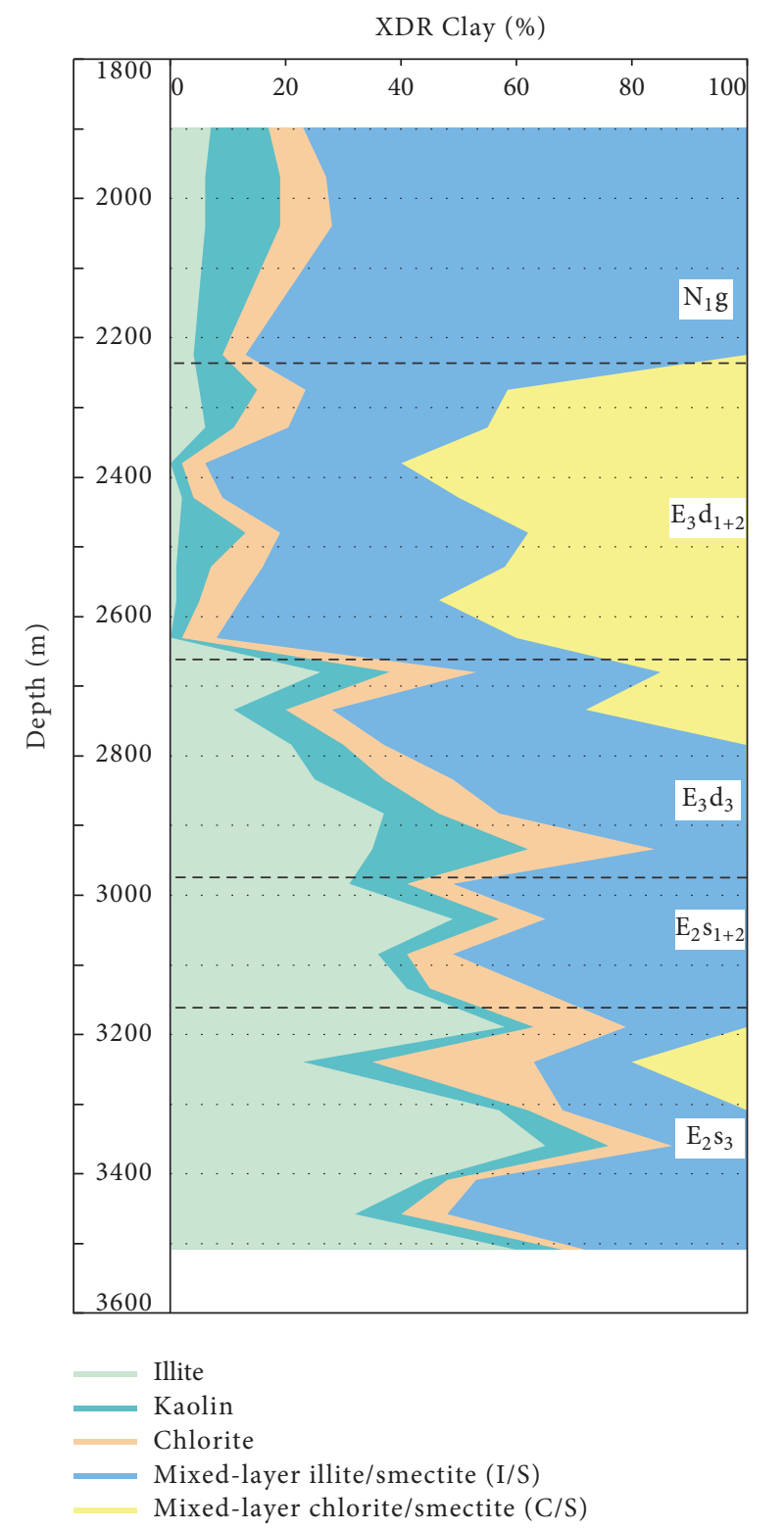

FIgURE 8: Mineralogical composition vertical distribution of interbedded mudstones based on XRD analysis.

that barely participates chemical diagenetic reactions except quartz overgrowth. As the research goes, however, more and more scholars realized that the dissolution of quartz grains and quartz overgrowth occurred during diagenesis stage [5359]. Experimental simulation also confirmed the dissolution of quartz occurred and, based on determinations of simulation experiment, experimental formula was obtained that quartz dissolution rates are a function of $\mathrm{pH}$, temperature, and alkaline ions concentration [55]. Although multiple factors can affect quartz dissolution, the predominant factor controlled quartz dissolution is pore fluid geochemical property $[55,59,60]$. Because of the stability of quartz, it is difficult to dissolve and commonly will become unstable in alkaline environments where dissolution and alternation is developed. Therefore, the dissolution of quartz, generally, indicates the

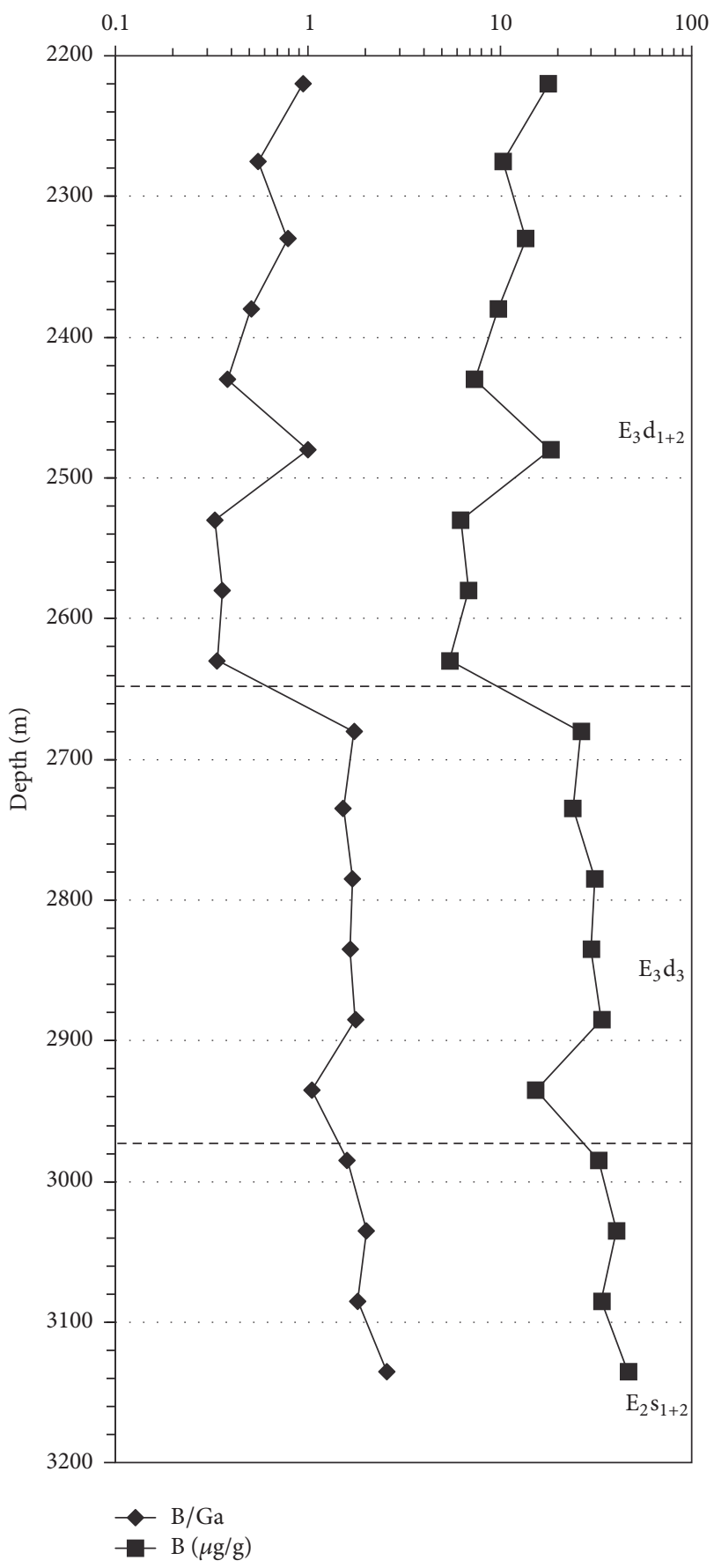

FIGURE 9: Plots showing the variations in the concentrations of $\mathrm{B}$ element and the ratio of $\mathrm{B} / \mathrm{Ga}$ with depth in mudstone of well BZ-1. $\mathrm{B}=$ boron; $\mathrm{Ga}=$ gallium.

alkaline aqueous medium environments as exemplified by many case studies [58-60]. The quartz dissolution in the study area is mainly observed in $\mathrm{E}_{2} \mathrm{~s}_{1+2}$ (Figure 6). During E2 $\mathrm{s}_{1+2}$, lacustrine basin experienced the arid climate of alkaline aqueous medium coupled with part hydrolysis of ferromagnesian-rich minerals, resulting in enrichment of sodium and potassium. With the enrichment of the alkaline ions, $\mathrm{pH}$ value of pore fluids became high. It thus can be 
concluded that the deposition aqueous medium environment may be alkaline during the period of diagenesis. In addition, local dissolution of detrital quartz grains can be observed in the $E_{3} d_{3}$ interval but is less common (Figure 6), which indicates that the aqueous medium environment was inferred to be affected by that of the $\mathrm{E}_{2} \mathrm{~s}_{1+2}$ interval.

Similarly conclusion can be drawn by the study on the analysis of trace element. Trace element is substantially sensible parameter indicating the salinity change which can be used to trace the pore fluid aqueous medium condition and therefore to deduce the deposition environment [6164]. The content of boron is positively correlated with the salinity, that is, the higher content of boron the higher salinity $[32,65]$. As is shown by the distribution of trace element of well BZ-1, the content of boron displays three stages increased with progressively increasing burial depth between $E_{3} d_{1+2}, E_{3} d_{3}$, and $E_{2} s_{1+2}$ (Figure 9). This trend indicates that the paleosalinity of $E_{2} s_{1+2}$ is the highest, $E_{3} d_{3}$ is second, and $E_{3} d_{1+2}$ is the least. It is worth noting that the layer containing the lowest paleosalinity in $\mathrm{E}_{3} \mathrm{~d}_{1+2}$ is well correlated with the layer containing widespread distribution of basalt in $\mathrm{E}_{3} \mathrm{~d}_{1+2}$. Therefore, it is not difficult to deduce that, during the deposition of $\mathrm{E}_{2} \mathrm{~s}_{1+2}$, lake basin is narrow and shallow with high salinity of alkaline aqueous medium environment. During the sedimentation of $\mathrm{E}_{3} \mathrm{~d}_{3}$, the basin experienced rapid subsidence and resulted in increasing in water depth and development of braided river delta. As a consequence, strong inputs of terrestrial deltaic fresh water significantly accelerated the pore fluids dilution causing decrease in salinity. However, braided river delta is not developed in $\mathrm{E}_{3} \mathrm{~d}_{1+2}$ which experienced weak inputs of terrestrial fresh water. Hence, the lowest paleosalinity in $\mathrm{E}_{3} \mathrm{~d}_{1+2}$ might not be the cause of input of terrestrial fresh water but interaction of pore fluids and basalt. Volcanic activities might have influenced the pore fluid salinity and further research is needed to understand the mechanism how volcanic activities influence the pore fluid salinity. Another parameter can be used to reveal that the paleosalinity is the ratios of $\mathrm{B} / \mathrm{Ga}$ that display the corresponding trend with the content of boron. All of this reveals that the pore fluid aqueous medium environment of $E_{2} s_{1+2}$ is alkalinity with high salinity. Besides that, the valuable information for the pore fluid aqueous medium environment of sandstone reservoirs can be provided by clay minerals composition. During the period of sedimentary process of $E_{2} s_{1+2}$, lake water was saline associated with arid climatic environments that favored enrichment of potassium and, with the increasing burial of depth as well as the increase of temperature and press, kaolinite transforms to illite based on XRD data.

The albitization of detrital K-feldspar and plagioclase is one of the most important diagenetic changes occurring in sandstone reservoir [66-68]. Many previous studies documented that the albitization of detrital K-feldspar commonly occurred in the alkaline aqueous medium environment $[60,69]$. The presence of detrital $\mathrm{K}$-feldspar albitization is observed mainly in $E_{2} s_{1+2}$ and also can be found in $E_{3} d_{3}$, but less common, indicating the alkaline aqueous medium environment during the sedimentary process of $E_{2} s_{1+2}$ as well as the weak alkaline condition of $\mathrm{E}_{3} \mathrm{~d}_{3}$.
In summary, based on the analysis of petrologic characteristics and pore fluid properties, evolution of pore fluids was investigated and three of distinguished stages are identified. (1) During $\mathrm{E}_{2} \mathrm{~s}_{1+2}$, lacustrine basin experienced the arid climate of alkaline aqueous medium coupled with part hydrolysis of ferromagnesian-rich minerals, resulting in enrichment of sodium and potassium with the highest content of boron and predominant clay minerals are potassium-rich illite and mixed-layer I/S (Figures 8, 9, and 10). (2) During $E_{3} d_{3}$, influx of fluvial fresh water together with hydrolysis of ferromagnesian mineral developed mixing aqueous medium environment diagenetic model (Figure 10). Mixing aqueous medium pore fluids in $\mathrm{E}_{3} \mathrm{~d}_{3}$ are characterized by interaction of pore fluids in both $E_{2} s_{1+2}$ and $E_{3} d_{1+2}$ and diagenetic processes exhibit integrated characteristic of both $\mathrm{E}_{2} \mathrm{~s}_{1+2}$ and $\mathrm{E}_{3} \mathrm{~d}_{1+2}$. The composition of the primary clay minerals is illite and mixed-layer I/S which may be caused by interaction of potassium-rich brine. (3) During $E_{3} d_{1+2}$, strong hydrolysis of unstable ferromagnesian mineral and weak influx of fluvial fresh water resulted in the pore fluids enriched in ferromagnesian minerals and ferromagnesian aqueous medium environment diagenetic model developed due to volcanic activities (Figure 10).

\subsection{Factors Controlling the Reservoir Quality}

5.2.1. Early Precipitation of Zeolite Associated with Basaltic Eruption. The pore fluids flow through the basalt strata dissolving the $\mathrm{Fe}^{2+}$ and $\mathrm{Mg}^{2+}$ of the igneous rocks to form a ferromagnesian aqueous medium environment where zeolite is precipitated in the intergranular pores. The presence of zeolite precipitation increases the resistance to compaction favoring the preservation of primary pores. However, during the thermal evolution stage of the source rocks, dissolution of zeolite developed due to expulsion of organic acid forming secondary pores (Figure 5). Therefore, it is easily inferred that proximal sandstone formations combined with the influence of strong hydrolysis of ferromagnesian minerals commonly are favorable for the development of sandstone porosity, such as transition zone of braided river delta development zone and basaltic eruption zone.

5.2.2. Impacting of Compaction on Reservoir Quality. A large number of exploration practices show that compaction is the main factor leading to the reduction of primary porosity of sandstone reservoirs. Therefore, the effective inhibition of compaction can significantly affect the preservation of pores and improve the reservoir quality. The volcanic rocks are widely distributed in the study area and vertical distribution is mainly focused in $E_{2} s_{1+2}$ and $E_{3} d_{1+2}$. During the volcanic eruption stage, volcanic conduit facies and overflow facies constructed I-shaped volcanic structure which formed roof support effect weakening the compaction of overlying formation [70]. Therefore, the primary pores can be substantially preserved improving the reservoir physical property.

5.2.3. Inhibition of Quartz Overgrowth and Dissolution of Detrital Quartz Grain. Quartz overgrowth is considered 


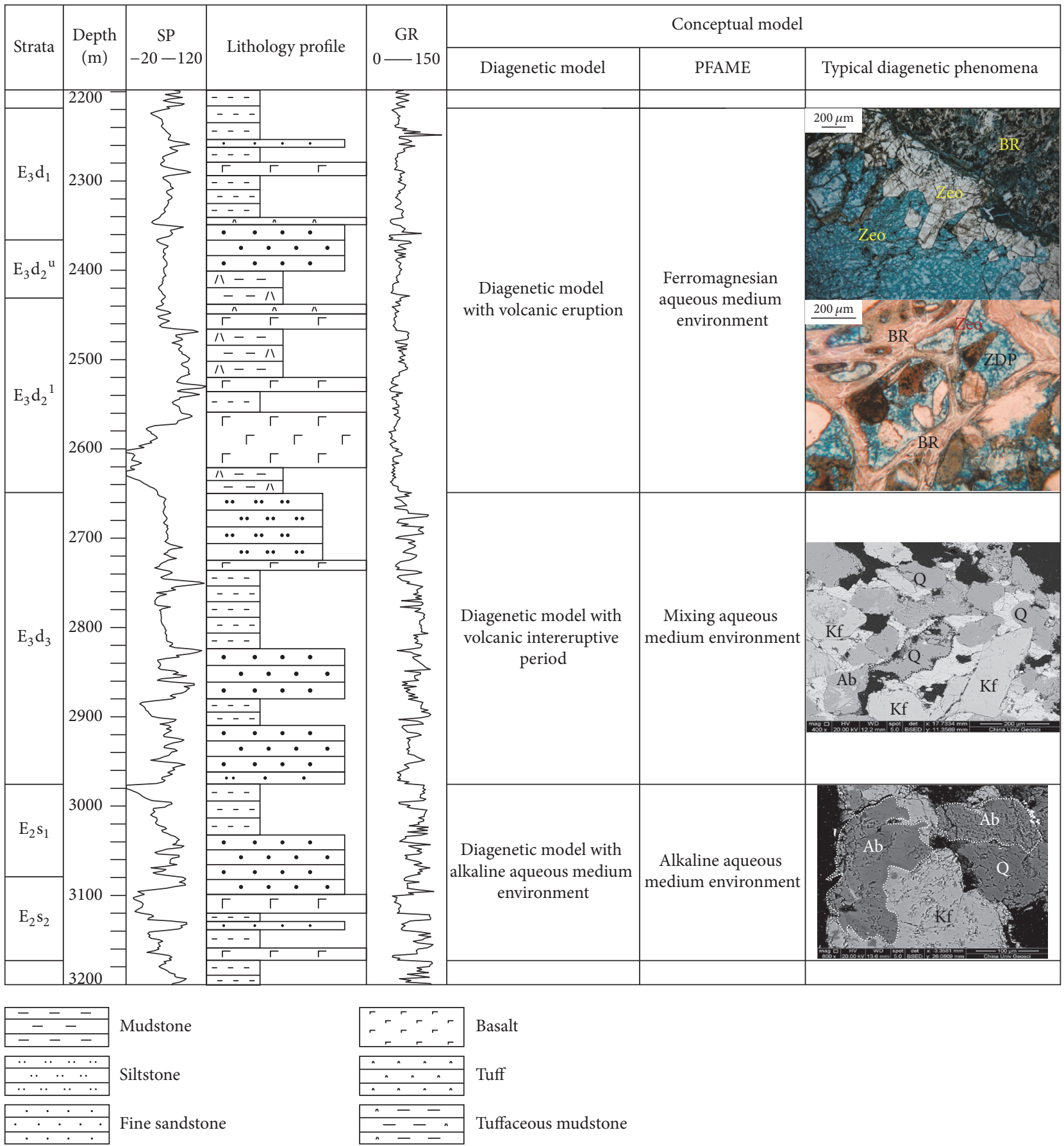

FIGURE 10: Vertical evolution of pore fluids properties and typical diagenetic phenomena of well BZ-1, Huanghekou Sag. Ab = albitization, $\mathrm{BR}=$ basalt rock fragment, $\mathrm{Kf}=\mathrm{K}$-feldspar, $\mathrm{PFAME}=$ pore fluid aqueous medium environment, $\mathrm{Q}=$ quartz, $\mathrm{ZDP}=$ zeolite dissolution pore, and $\mathrm{Zeo}=$ zeolite

the main factor that reduced the porosity of medium-deep reservoirs and commonly $1 \%$ of quartz overgrowth resulted in $10 \%$ of the pore loss [71]. Therefore, the pore preservation of medium-deep reservoirs can be achieved by inhibiting the chemical compaction of quartz. In the study area, the quartz grain surface observed the presence of ctenoid dolomite encrustation developed under the alkaline aqueous medium environment, effectively inhibiting the overgrowth of quartz
(Figure 7(d)). As a result, the pores can be better preserved. As is shown by the porosity data in well BZ-1, there is no significant decrease in porosity with progressively increasing burial depth between $\mathrm{E}_{3} \mathrm{~d}_{1+2}, \mathrm{E}_{3} \mathrm{~d}_{3}$, and $\mathrm{E}_{2} \mathrm{~s}_{1+2}$ (Figure 3 ). Furthermore, secondary pores produced resulted from the dissolution of detrital quartz also found based on thin section observation which improved the quality of reservoir (Figures 6(a), 6(b), and 6(c)). 
5.3. Implications for Petroleum Exploration. The study has broad implications for exploration and development in other deeply buried sandstone reservoirs, especially but not exclusively related to volcanic activities. Sandstone reservoirs with development of volcanic rocks have not been considered prime potential hydrocarbon reservoirs due to poor reservoir quality. The present study, however, demonstrated that ferromagnesian-rich pore fluid aqueous medium environment resulted from volcanic activities developing typical diagenetic events such as precipitation and dissolution of zeolite associated with basaltic eruption effectively improving the reservoir quality. In turn, related diagenetic processes record the pore fluid property which provides us with new insight into investigating the pore fluid evolution and predicting the reservoir quality. Meanwhile, volcanic conduit facies and overflow facies constructed I-shaped volcanic structure which increased resistance but reduced compaction of strata, preserving the primary pores and improving the reservoir quality.

\section{Conclusions}

Pore fluid evolution influenced by volcanic activities in sandstone reservoirs has a critical impact on diagenetic processes which controlled the reservoir quality, as exemplified by deeply buried sandstone reservoirs in the Huanghekou Sag, Bohai Bay Basin, China. On the basis of our studies, the following conclusions can be drawn.

(1) Volcanic activities exert a significant influence on pore fluid properties depending on volcanic activity intensity. Evolution of pore fluids can be divided into three stages corresponding to volcanic activities: (1) $\mathrm{E}_{2} \mathrm{~s}_{1+2}$ : alkaline aqueous medium environment is developed with insignificant influence by volcanic activities, which can be interpreted as alkaline lake basin aqueous medium diagenetic model; (2) $\mathrm{E}_{3} \mathrm{~d}_{3}$ : affected by influx of fluvial fresh water together with hydrolysis of ferromagnesian mineral, mixing aqueous medium environment occurred and volcanic intereruptive period diagenetic model was established; (3) $\mathrm{E}_{3} \mathrm{~d}_{1+2}$ : multiphase volcanic activities resulted in the formation of ferromagnesian aqueous medium environment and development of basal eruption diagenetic model.

(2) The vertical distribution of pore fluids with varied properties in different intervals controls the diagenetic processes and reservoir quality. (1) Alkaline aqueous medium pore fluids formed in $\mathrm{E}_{2} \mathrm{~s}_{1+2}$, causing quartz dissolution, K-feldspar albitization, and dolomite encrustation. (2) Ferromagnesian pore fluids in $\mathrm{E}_{3} \mathrm{~d}_{1+2}$ resulted in zeolite precipitation in early diagenesis and zeolite dissolution during thermal evolution stage due to expulsion of organic acid. In addition, the predominant clay mineral is mixed-layer $\mathrm{C} / \mathrm{S}$ influenced by hydrolysis of unstable ferromagnesian-rich mineral resulting from volcanic activities. (3) Mixing aqueous medium pore fluids in $\mathrm{E}_{3} \mathrm{~d}_{3}$ are characterized by interaction of pore fluids in both $\mathrm{E}_{2} \mathrm{~s}_{1+2}$ and $\mathrm{E}_{3} \mathrm{~d}_{1+2}$. Therefore, the diagenetic processes exhibits integrated characteristic of both $\mathrm{E}_{2} \mathrm{~s}_{1+2}$ and $\mathrm{E}_{3} \mathrm{~d}_{1+2}$.

(3) A series of controlling factors that played positive effect in the reservoirs quality are concluded including dolomite encrustation inhibited quartz overgrowth developments, quartz and zeolite dissolution formed secondary pores, and I-shaped igneous structure increased the resistance of compaction.

\section{Conflicts of Interest}

The authors declare that there are no conflicts of interest regarding the publication of this paper.

\section{Acknowledgments}

This research was funded by the National Natural Science Foundation of China (no. 41572084) and the National Science and Technology Major Project (no. 2016ZX05024-003-007). Thanks are due to the Tianjin Branch of the China National Offshore Oil Corporation for providing data used in this study and the permission to publish the results.

\section{References}

[1] S. Bloch, R. H. Lander, and L. Bonnell, "Anomalously high porosity and permeability in deeply buried sandstone reservoirs: Origin and predictability," AAPG Bulletin, vol. 86, no. 2, pp. 301-328, 2002.

[2] J. M. Ajdukiewicz, P. H. Nicholson, and W. L. Esch, "Prediction of deep reservoir quality using early diagenetic process models in the jurassic norphlet formation, gulf of Mexico," $A A P G$ Bulletin, vol. 94, no. 8, pp. 1189-1227, 2010.

[3] X. Pu, L. Zhou, W. Wang et al., "Medium-deep clastic reservoirs in the slope area of Qikou sag, Huanghua depression, Bohai Bay Basin," Petroleum Exploration and Development, vol. 40, no. 1, pp. 38-51, 2013.

[4] F. Hao, X. Zhou, Y. Zhu, X. Bao, and Y. Yang, "Charging of the Neogene Penglai 19-3 field, Bohai Bay Basin, China: Oil accumulation in a young trap in an active fault zone," AAPG Bulletin, vol. 93, no. 2, pp. 155-179, 2009.

[5] C. G. Xu and W. C. Lai, "Predication technologies of Paleogene mid-deep reservoir and their application in Bohai Sea," China offshore oil and gas, vol. 4, pp. 231-236, 2005.

[6] S. Jiang, D. S. Cai, X. M. Zhu, G. H. Zhu, and X. L. Hu, "Diagenesis of Liaozhong sag in Liaohe depression and pore evolution in its middle-deep strata," Oil and Gas Geology, vol. 28, no. 3, pp. 362-369, 2007, [In Chinese with English abstract].

[7] Y.-J. Wang, M.-S. Feng, J. Wang, Q.-L. Xia, X.-H. Zhou, and W.C. Lai, "Characteristics of high-quality reservoir of mediumdeep paleogene in shinan slope area, bozhong depression," Journal of Mineralogy and Petrology, vol. 32, no. 3, pp. 77-84, 2012.

[8] H. Zhu, Y. Liu, Y. Wang, X. Zhou, and X. Yang, "Volcanic eruption phases and 3-D characterization of volcanic rocks in BZ34-9 block of Huanghekou Sag, Bohai Bay Basin," Earth Science - Journal of China University of Geosciences, vol. 39, no. 9, pp. 1309-1316, 2014. 
[9] B. L. Winter, C. M. Johnson, J. A. Simo, and J. W. Valley, "Paleozoic fluid history of the Michigan basin: Evidence from dolomite geochemistry in the middle Ordovician St. Peter Sandstone," Journal of Sedimentary Research, no. 65, pp. 306320, 1995.

[10] S. Morad, K. Al-Ramadan, J. M. Ketzer, and L. F. De Ros, "The impact of diagenesis on the heterogeneity of sandstone reservoirs A review of the role of depositional facies and sequence stratigraphy," AAPG Bulletin, vol. 94, no. 8, pp. 12671309, 2010.

[11] K. Bjørlykke and J. Jahren, "Open or closed geochemical systems during diagenesis in sedimentary basins: Constraints on mass transfer during diagenesis and the prediction of porosity in sandstone and carbonate reservoirs," AAPG Bulletin, vol. 96, no. 12, pp. 2193-2214, 2012.

[12] B. Ma, K. A. Eriksson, Y. Cao, Y. Jia, Y. Wang, and B. C. Gill, "Fluid flow and related diagenetic processes in a rift basin: Evidence from the fourth member of the Eocene Shahejie Formation interval, Dongying depression, Bohai Bay Basin, China," AAPG Bulletin, vol. 100, no. 11, pp. 1633-1662, 2016.

[13] L. C. Amajor and A. M. Gbadebo, "Oilfield brines of meteoric and connate origin in the eastern Niger Delta," Journal of Petroleum Geology, vol. 15, no. 4, pp. 481-488, 1992.

[14] K. Bjørlykke, "Fluid flow in sedimentary basins," Sedimentary Geology, vol. 86, no. 1-2, pp. 137-158, 1993.

[15] M. A. Bustillo and A. M. Alonso-Zarza, "Overlapping of pedogenesis and meteoric diagenesis in distal alluvial and shallow lacustrine deposits in the Madrid Miocene Basin, Spain," Sedimentary Geology, vol. 198, no. 3-4, pp. 255-271, 2007.

[16] J. W. Bishop, D. A. Osleger, I. P. Montãez, and D. Y. Sumner, "Meteoric diagenesis and fluid-rock interaction in the middle Permian capitan backreef: Yates formation, slaughter canyon, New Mexico," AAPG Bulletin, vol. 98, no. 8, pp. 1495-1519, 2014.

[17] K. Bjørlykke, "Clay mineral diagenesis in sedimentary basins A key to the prediction of rock properties. Examples from the North Sea Basin," Clay Minerals, vol. 33, no. 1, pp. 14-34, 1998.

[18] K. Bjørlykke, "Petroleum geoscience: From sedimentary environments to rock physics," Petroleum Geoscience: From Sedimentary Environments to Rock Physics, pp. 1-508, 2010.

[19] F. O. Amadi, R. P. Major, and L. R. Baria, “Origins of gypsum in deep carbonate reservoirs: Implications for hydrocarbon exploration and production," AAPG Bulletin, vol. 96, no. 2, pp. 375-390, 2012.

[20] C. M. Bethke and S. Marshak, "Brine migrations across North America - the plate tectonics of groundwater," Annual Review of Earth \& Planetary Sciences, vol. 18, pp. 287-315, 1990.

[21] B. H. Hartmann, K. Ramseyer, and A. Matter, "Diagenesis and pore-water evolution in permian sandstones, gharif formation, Sultanate of Oman," Journal of Sedimentary Research, vol. 70, no. 3, pp. 533-544, 2000.

[22] J. Wang, Y. Cao, K. Liu, J. Liu, X. Xue, and Q. Xu, "Pore fluid evolution, distribution and water-rock interactions of carbonate cements in red-bed sandstone reservoirs in the Dongying Depression, China," Marine and Petroleum Geology, vol. 72, pp. 279-294, 2016.

[23] S. P. Dutton and R. G. Loucks, "Reprint of: Diagenetic controls on evolution of porosity and permeability in lower Tertiary Wilcox sandstones from shallow to ultradeep (200-6700m) burial, Gulf of Mexico Basin, U.S.A.," Marine and Petroleum Geology, vol. 27, no. 8, pp. 1775-1787, 2010.
[24] S. Morad, J. M. Ketzer, and L. R. De Ros, "Spatial and temporal distribution of diagenetic alterations in siliciclastic rocks: Implications for mass transfer in sedimentary basins," Sedimentology, vol. 47, no. 1, pp. 95-120, 2000.

[25] K. Bjørlykke, "Relationships between depositional environments, burial history and rock properties. Some principal aspects of diagenetic process in sedimentary basins," Sedimentary Geology, vol. 301, pp. 1-14, 2014.

[26] H. L. Wycherley, J. Parnell, G. R. Watt, H. Chen, and A. J. Boyce, "Indicators of hot fluid migration in sedimentary basins: Evidence from the UK Atlantic margin," Petroleum Geoscience, vol. 9, no. 4, pp. 357-374, 2003.

[27] W. Wang, X. H. Yang, Q. B. Wang, J. R. Ye, H. T. Zhu, and H. Li, "Characterization and controlling factors of sandstone reservoirs in basalt development areas: an example from comparison between BZ3-9 and KL6 area in South of Bohai Sea," Earth Science, vol. 42, no. 4, pp. 570-586, 2017, [In Chinese with English abstract].

[28] M. B. Allen, D. I. M. Macdonald, Z. Xun, S. J. Vincent, and C. Brouet-Menzies, "Early Cenozoic two-phase extension and late Cenozoic thermal subsidence and inversion of the Bohai Basin, northern China," Marine and Petroleum Geology, vol. 14, no. 7-8, pp. 951-972, 1997.

[29] L.-Y. Hsiao, S. A. Graham, and N. Tilander, "Seismic reflection imaging of a major strike-slip fault zone in a rift system: Paleogene structure and evolution of the Tan-Lu fault system, Liaodong Bay, Bohai, offshore China," AAPG Bulletin, vol. 88, no. 1, pp. 71-97, 2004.

[30] J. Qi and Q. Yang, "Cenozoic structural deformation and dynamic processes of the Bohai Bay basin province, China," Marine and Petroleum Geology, vol. 27, no. 4, pp. 757-771, 2010.

[31] C. T. Walker, "Evaluation of boron as a paleosalinity indicator and its application to offshore prospects," AAPG Bulletin, vol. 52, no. 5, pp. 751-766, 1968.

[32] E. L. Couch, "Calculation of paleosalinities from boron and clay mineral data," American Association of Petroleum Geologists Bulletin, vol. 55, no. 10, pp. 1829-1837, 1971.

[33] B. Legler, J. W. Schneider, U. Gebhardt, D. Merten, and R. Gaupp, "Lake deposits of moderate salinity as sensitive indicators of lake level fluctuations: Example from the Upper Rotliegend saline lake (Middle-Late Permian, Northeast Germany)," Sedimentary Geology, vol. 234, no. 1-4, pp. 56-69, 2011.

[34] C. Ye, Y. Yang, X. Fang, and W. Zhang, "Late Eocene clay boronderived paleosalinity in the Qaidam Basin and its implications for regional tectonics and climate," Sedimentary Geology, vol. 346, pp. 49-59, 2016.

[35] S. Landergren, "On the Distribution of Boron on Different Size Classes in Marine Clay Sediments," GFF, vol. 80, no. 1, pp. 104107, 1958.

[36] D. M. Moore and R. C. Reynolds, X-ray Diffraction and the Identification and Analysis of Clay Minerals, Oxford University Press, 1997.

[37] S. Hillier, "Quantitative Analysis of Clay and other Minerals in Sandstones by X-Ray Powder Diffraction (XRPD)," Clay Mineral Cements in Sandstones, pp. 663-676, 2003.

[38] G. Chen, "Zeolite minerals and their relation to oil and gas accumulation in the reservoir formations in karamay oil field," Acta Petrolei Sinica, vol. 13, no. 3, pp. 45-51, 1992, [In Chinese with English abstract]. 
[39] R. H. Mariner and R. C. Surdam, "Alkalinity and formation of zeolites in saline alkaline lakes," Science, vol. 170, no. 3961, pp. 979-980, 1970.

[40] S. Han, H. Yu, C. Si, S. Chen, N. Chen, and L. Yu, "Corrosion of analcite in reservoir of Junggar Basin," Shiyou Xuebao/Acta Petrolei Sinica, vol. 28, no. 3, pp. 51-62, 2007.

[41] S. F. Zhu, X. M. Zhu, X. L. Wang, and Z. Y. Liu, "Zeolite diagenesis and its control on petroleum reservoir quality of Permian in northwestern margin of Junggar Basin, China," Science China Earth Sciences, vol. 55, no. 3, pp. 386-396, 2012.

[42] R. L. Hay, "Zeolites and zeolitic reactions in sedimentary rocks," Special Paper of the Geological Society of America, vol. 85, pp. 1122, 1966.

[43] M. D. Su and C. L. Dai, "Geological feature and genesis of zeolite in the Mesozoic Volcanic Rocks in east China," Scientia Geologica Sinica, vol. 2, pp. 116-125, 1983, [In Chinese with English abstract].

[44] H. Li, Y. Q. Liu, H. Liang et al., "Lithology and original analysis of sublacustrine hydrothermal deposits characterized by analcime, sanidine, dolomite, quaterz, etc. in Lucaogou Formation, Middile Permian, Santanghu Basin, Northeast Xinjiang, China," Acta Petrolei Sinica, vol. 30, no. 2, pp. 205-218, 2012, [In Chinese with English abstract].

[45] G. K. Moncure, R. C. Surdam, and H. L. McKague, "Zeolite diagenesis below pahute mesa, nevada test site," Clays and Clay Minerals, vol. 29, no. 5, pp. 385-396, 1981.

[46] L. Bettison-Varga and I. D. R. Mackinnon, "The role of randomly mixed-layered chlorite/smectite in the transformation of smectite to chlorite," Clays and Clay Minerals, vol. 45, no. 4, pp. 506-516, 1997.

[47] H. Lindgreen, V. A. Drits, B. A. Sakharov et al., "The structure and diagenetic transformation of illite-smectite and chloritesmectite from North Sea Cretaceous-Tertiary chalk," Clay Minerals, vol. 37, no. 3, pp. 429-450, 2002.

[48] S. M. Xu, C. M. Lin, X. F. Wang et al., "Diagenesis and Its Effect on Reservoir of Member 2-3 of the Lower Shihezi Formation in Daniudi Gas Field, Ordos Basin," Geoscience, vol. 25, no. 5, pp. 909-916, 2011, [In Chinese with English abstract].

[49] K. Bjørlykke, "Open-system chemical behaviour of Wilcox Group mudstones. How is large scale mass transfer at great burial depth in sedimentary basins possible? A discussion," Marine and Petroleum Geology, vol. 28, no. 7, pp. 1381-1382, 2011.

[50] F. L. Lynch, L. E. Mack, and L. S. Land, "Burial diagenesis of illite/smectite in shales and the origins of authigenic quartz and secondary porosity in sandstones," Geochimica et Cosmochimica Acta, vol. 61, no. 10, pp. 1995-2006, 1997.

[51] Y. M. Metwally and E. M. Chesnokov, "Clay mineral transformation as a major source for authigenic quartz in thermomature gas shale," Applied Clay Science, vol. 55, pp. 138-150, 2012.

[52] B. Thyberg, J. Jahren, T. Winje, K. Bjørlykke, J. I. Faleide, and Ø. Marcussen, "Quartz cementation in Late Cretaceous mudstones, northern North Sea: Changes in rock properties due to dissolution of smectite and precipitation of micro-quartz crystals," Marine and Petroleum Geology, vol. 27, no. 8, pp. 17521764, 2010.

[53] P. C. Bennett, "Quartz dissolution in organic-rich aqueous systems," Geochimica et Cosmochimica Acta, vol. 55, no. 7, pp. 1781-1797, 1991.
[54] A. J. Gratz and P. Bird, "Quartz dissolution: Theory of rough and smooth surfaces," Geochimica et Cosmochimica Acta, vol. 57, no. 5, pp. 977-989, 1993.

[55] P. M. Dove, "The dissolution kinetics of quartz in sodium chloride solutions at $25^{\circ}$ to $300^{\circ} \mathrm{C}$," American Journal of Science, vol. 294, no. 6, pp. 665-712, 1994.

[56] J. W. Tester, W. G. Worley, B. A. Robinson, C. O. Grigsby, and J. L. Feerer, "Correlating quartz dissolution kinetics in pure water from 25 to $625^{\circ}$ C, Geochimica et Cosmochimica Acta, vol. 58, no. 11, pp. 2407-2420, 1994.

[57] W. G. Worley, J. W. Tester, and C. O. Grigsby, "Quartz Dissolution Kinetics from $100-200^{\circ} \mathrm{C}$ as a Function of $\mathrm{pH}$ and Ionic Strength," AIChE Journal, vol. 42, no. 12, pp. 3442-3455, 1996.

[58] L. W. Qiu, Z. X. Jiang, W. X. Chen, X. H. Li, and Z. D. Xiong, "A new type of secondary porosity Quartz Dissolution Poroity," Acta Petrolei Sinica, vol. 20, no. 4, pp. 621-627, 2002, [In Chinese with English abstract].

[59] D. L. Han, Z. Li, and W. F. Li, "Heterogeneous Features of Quartz Grain Dissolution of Cretaceous Sandstone Reservoir in the Kuqa Depression and Its Major Controlling factors," Acta Geologica Sinica, vol. 85, no. 2, pp. 257-261, 2011, [In Chinese with English abstract].

[60] H. Zhu, D. Zhong, J. Yao et al., "Alkaline diagenesis and its effects on reservoir porosity: a case study of Upper Triassic Chang 7 tight sandstones in Ordos Basin, NW China," Petroleum Exploration and Development, vol. 42, no. 1, pp. 5159, 2015.

[61] R. L. Cullers, "The controls on the major and trace element variation of shales, siltstones, and sandstones of PennsylvanianPermian age from uplifted continental blocks in Colorado to platform sediment in Kansas, USA," Geochimica et Cosmochimica Acta, vol. 58, no. 22, pp. 4955-4972, 1994.

[62] Y. Miao, S. X. Sang, S. Y. Chen, C. J. Liu, and J. B. Ouyang, "Trace element characteristics and their geological significances in Permo-Carboniferous dark mudstone in Jiyang Depression," Geochimica, vol. 38, no. 1, pp. 57-67, 2009, [In Chinese with English abstract].

[63] R. C. Zheng and M. Q. Liu, "Study on Palaeosalinity of Chang-6 oil Reservoir set in Ordos Basin,” Oil and Gas Geology, vol. 20, no. 1, pp. 20-25, 1999, [In Chinese with English abstract].

[64] Z. J. Zhu, H. D. Chen, L. B. Lin, and Y. Fan, "Signification and characteristic of the trace element ratios of the sandstone in silurian xiaoheba formation in southeastern sichuan province and western hunan province," Geological Sciences and Technology Information, vol. 29, no. 2, pp. 24-30, 2010, [In Chinese with English abstract].

[65] G. Liu and D. S. Zhou, "Application of microelements analysis in identifying sedimentary environment," Petroleum Geology and Experiment, vol. 29, no. 3, pp. 307-310, 2007, [In Chinese with English abstract].

[66] E. F. McBride, "Diagenetic processes that affect provenance determination in sandstones," in Provenance of arenites, pp. 95113, Spring Netherlands, 1985.

[67] S. Morad, "Albitized microcline grains of post-depositional and probable detrital origins in Brøttum Formation sandstones (Upper Proterozoic), Sparagmite Region of southern Norway," Geological Magazine, vol. 125, no. 3, pp. 229-239, 1988.

[68] K. L. Milliken, "Late Diagenesis and Mass Transfer in Sandstone-Shale Sequences," Treatise on Geochemistry, vol. 7-9, pp. 159-190, 2003. 
[69] G. F. Yang, S. G. Zhuo, B. Niu, and J. J. Er, "Albitization of detrital feldspar in cretaceous sandstones from the songliao basin," Geological Review, vol. 49, no. 2, pp. 155-161, 2003.

[70] YB. Chai, B. Yang, QB. Wang, CM. Niu, and H. Li, "A contrastive analysis on the impact of volcanic rock on compaction of BZ34 area in Huanghekou Depression," Geological Science and Technology Information, no. 1, pp. 80-86, 2016, [In Chinese with English abstract].

[71] S. T. Paxton, J. O. Szabo, J. M. Ajdukiewicz, and R. E. Klimentidis, "Construction of an intergranular volume compaction curve for evaluating and predicting compaction and porosity loss in rigid-grain sandstone reservoirs," AAPG Bulletin, vol. 86, no. 12, pp. 2047-2067, 2002. 

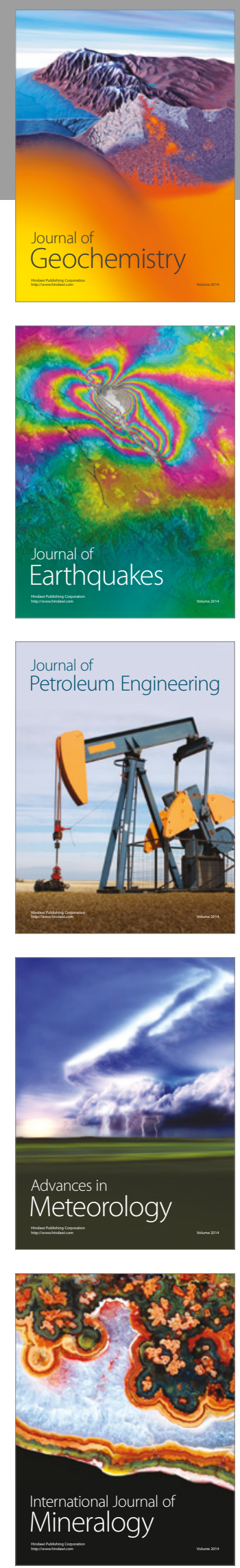
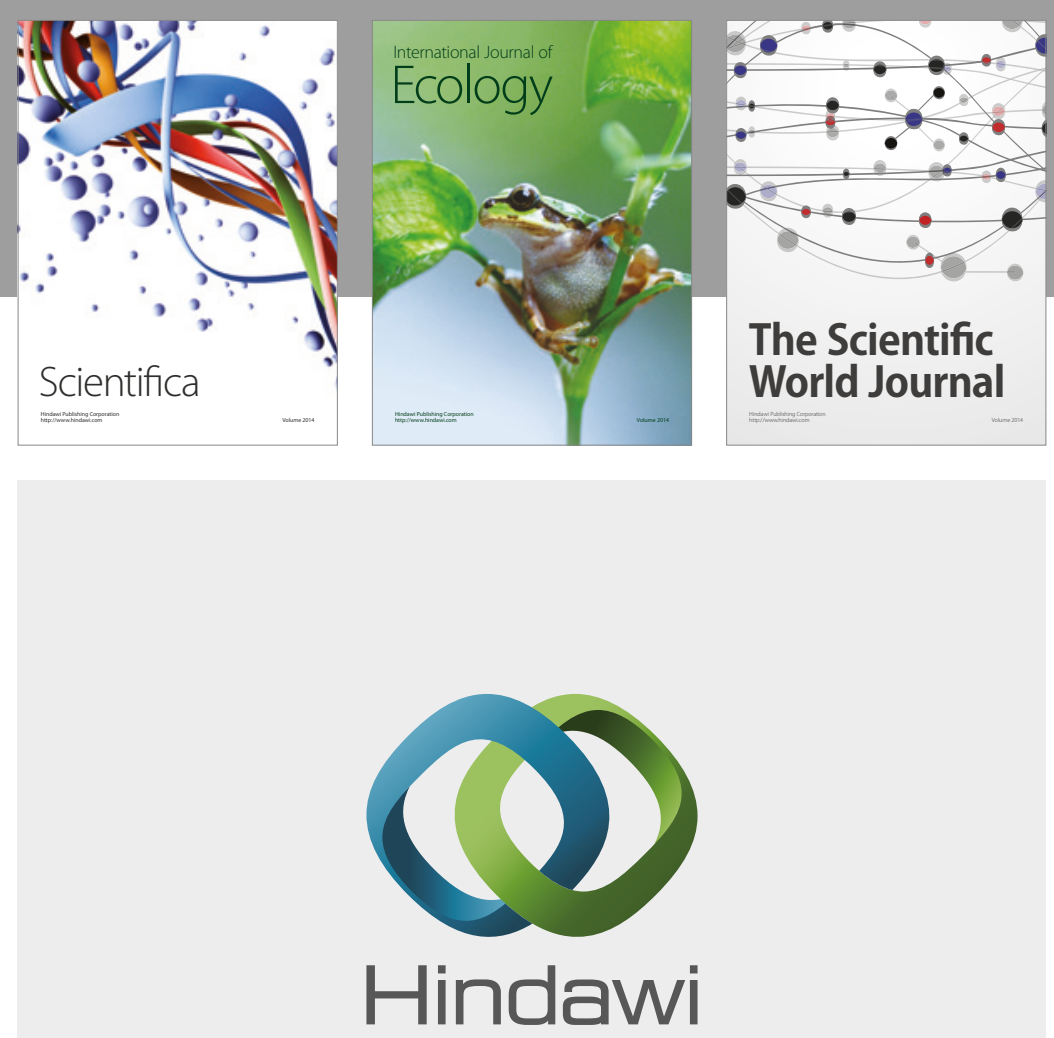

Submit your manuscripts at

https://www.hindawi.com
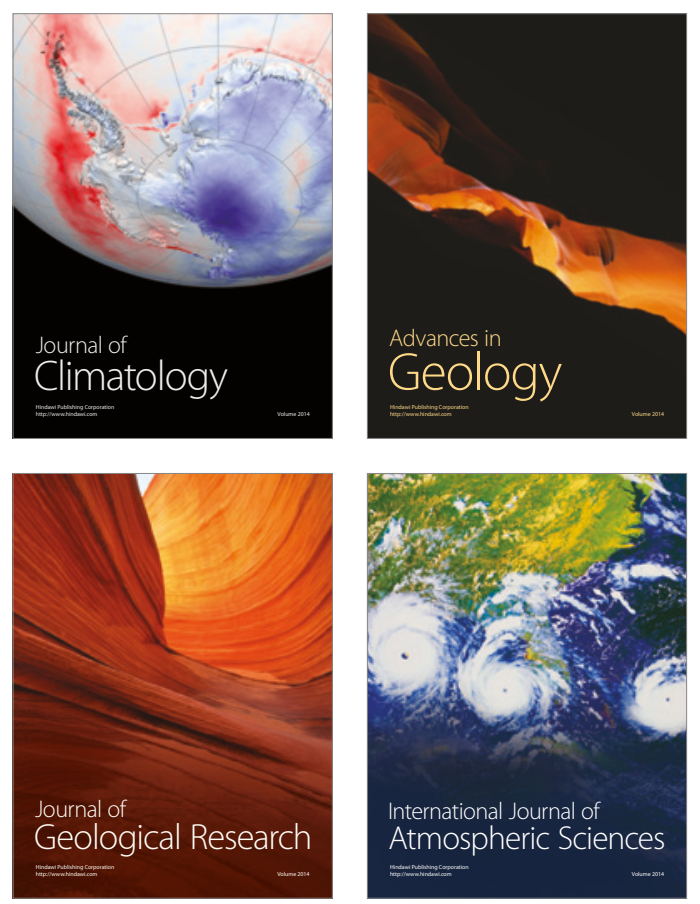

The Scientific

World Journal
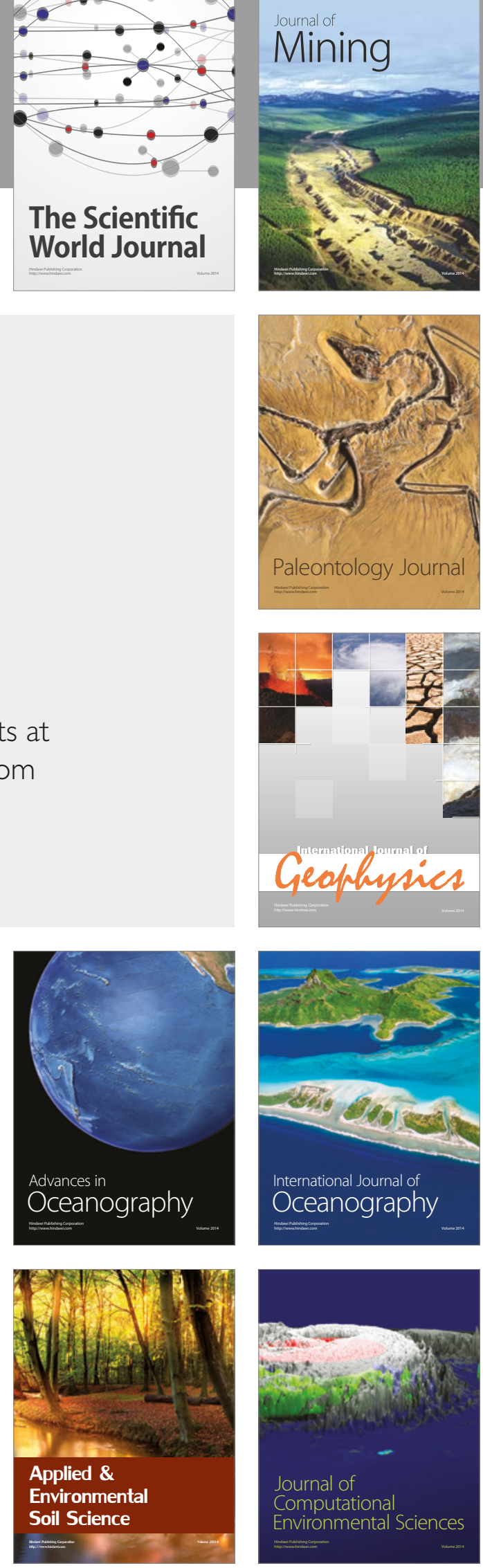